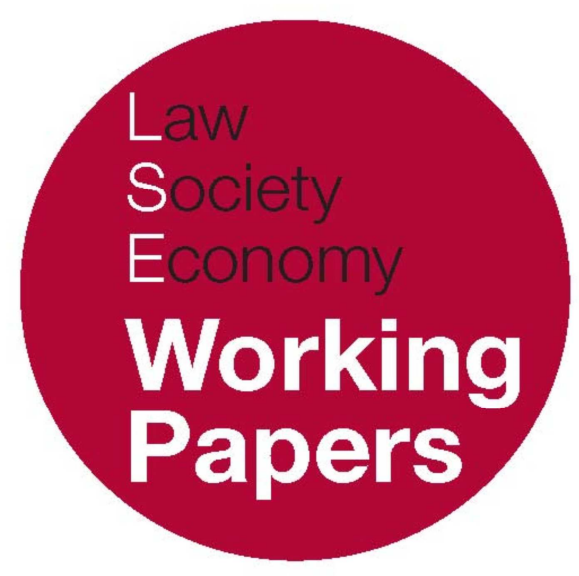

\title{
The Rule in Foss v Harbottle is Dead; Long Live the Rule in Foss v Harbottle
}

\author{
David Kershaw \\ LSE Law, Society and Economy Working Papers 5/2013 \\ London School of Economics and Political Science \\ Law Department
}

This paper can be downloaded without charge from LSE Law, Society and Economy Working Papers at: www.lse.ac.uk/collections/law/wps/wps.htm and the Social Sciences Research Network electronic library at: http://ssrn.com/abstract=2209061.

(C) David Kershaw. Users may download and/or print one copy to facilitate their private study or for non-commercial research. Users may not engage in further distribution of this material or use it for any profit-making activities or any other form of commercial gain. 


\title{
The Rule in Foss v Harbottle is Dead; Long Live the Rule in Foss v Harbottle
}

\author{
David Kershaw *
}

\begin{abstract}
The proper plaintiff rule reflects the elemental legal principle that only the right-holder is entitled to enforce the right. At common law, as a corollary of this principle, only when the general meeting was incapable of acting in the corporate interest could a derivative action be brought. It followed from this principle that wrongdoer control of the shareholder meeting was a pre-requisite to derivative litigation. The Companies Act 2006 introduced what is considered to be a 'new' derivative action mechanism. Although the Act is silent about the wrongdoer control requirement, it is widely understood to have abolished it. Central to this understanding is the view that this is what Parliament intended, as supported by a view of the mischief of the Act and by several ministerial statements. However, careful attention to the extra-legislative record as well as to the rules on statutory interpretation render this view of the mischief of the Act inaccurate and these statements of ministerial intent inadmissible. Detaching our interpretation of the Act from reliance upon this record opens up unexpected possibilities when combined with observations from recent authority which suggest that the Act's reforms were not intended to abolish the proper plaintiff principle. A compelling case can be made that wrongdoer control remains as a threshold condition to derivative litigation.
\end{abstract}

\footnotetext{
* Professor of Law, London School of Economics. I would like to thank Carsten Gerner-Beuerle, Marlies Braun, Leslie Kosmin, Ewan McGaughey, Gemma Mootoo-Rajah, James Palmer, Arad Reisberg, Chris Riley and Sarah Worthington for comments on earlier versions of this article.
} 


\section{INTRODUCTION}

Consensus practitioner or academic opinion is not an admissible interpretative aid in determining the purpose and meaning of legislation. Yet in practice such consensus views may infiltrate the interpretative process. This problem is particularly acute in the context of legislative reform projects where there is a consensus narrative as to both the prior legal problem and the intended legislative response. When 'we all know' what the legislative change was intended to remedy it is easy to ride rough shot over legislative ambiguities that do not fit with the narrative. In such contexts there is a risk that consensus views, although formally inadmissible, disperse literal legislative ambiguity and its exploration. In doing so academic and practitioner consensus becomes a latent, and illegitimate, source of law. One area raising such problems is the recent reform of derivative action law in the United Kingdom.

Prior to the Companies Act 2006, English company law made it very difficult to bring derivative litigation. Through a common law rule known alternatively as the Rule in Foss $v$ Harbottle or the proper plaintiff rule, English law affirmed the fundamental right of the company through its organs to make the litigation decision in relation to a breach of an obligation owed to it. It allowed this right to be circumvented only in very restrictive circumstances. Derivative actions could only be brought in relation to breaches of duty which injured the company and benefited the directors personally (wrongs that were generally referred to as 'fraud') and where the directors in breach of duty - the wrongdoers - had de jure or de facto control of the general meeting of the company through their shares. This meant that derivative actions were simply unavailable in relation to negligence claims against any company or in relation to any claim at all against a director of a widely held company, where a wrongdoing director would never be in control of the general meeting.

These rules were thought by many to be too complex, incoherent and too restrictive. The Law Commission was asked to consider the state of the law and to make recommendations. They did so judiciously, concluding that the law was too restrictive and in places unclear. They recommended the introduction of a judge controlled process which would allow derivative actions to be commenced in relation to any breach of duty, but provided the court with the power to determine whether such actions should be able to continue. It was proposed that this power would to be exercised in accordance with a set of factors - such as whether in a hypothetical director's view the litigation would be in interests of the company which in some instances would be determinative of the court's decision and in others merely factors to be considered by the court in exercising their discretion. The Commission's recommendation that reform was necessary was accepted by the Government and reforms were enacted in Part 11 of the Companies Act 2006.

Part 11 is widely viewed by corporate academics and practitioners as a significant corporate legal moment involving the introduction of a 'new' derivative 
claim mechanism. ${ }^{1}$ For many it represents the end of the era of the Rule of Foss $v$ Harbottle. Professor Davies observes in this regard that the common law derivative action rules have been 'consigned to the dustbin'. ${ }^{2}$ From now on the question whether a derivative action (referred to by the Act as a derivative claim) can be brought will be dealt with in accordance with the provisions of the Act without any need to engage with the prior rules. More specifically, the statute provides that there is no 'fraud' restriction on the types of breach of duty that could form the basis of a derivative action, and it is widely understood to have abolished the threshold requirement of having to show wrongdoer control. The former change was set forth explicitly in the Act which contains an expanded list of wrongs in relation to which members can bring a derivative claim. ${ }^{3}$ However, wrongdoer control is not addressed directly by the Act. Its abrogation is inferred.

Many open issues and questions remain about how the courts will apply Part 11, the most fundamental of which involve the relationship between Part 11 and the common law rules on derivative actions. On one view, there is no such relationship because the common law rules have been consigned to the dustbin by Part 11 which represents a clean regulatory slate. Yet there remain elements of doubt about this 'clean-slate' approach. For example, Daniel Lightman has recently argued that Part 11 has no effect on the common law rules on multiple derivative actions because Part 11 only addresses direct derivative actions. ${ }^{4}$ More fundamental still is the question of the status and contemporary implications of the proper plaintiff rule. Recent first instance decisions raise the issue of whether this rule may not have been abolished by the Act. ${ }^{5}$ Attention to the Explanatory Notes to the Company Law Reform Bill and to Parliamentary debates supports this position. But treating the proper plaintiff rule as a still applicable substantive rule of law has the potential to transform our understanding of Part 11.

The proper plaintiff rule set forth in Foss $v$ Harbottle is the parent of the wrongdoer control pre-requisite to bringing derivative litigation at common law. It provides that only the company itself can bring litigation for the infringement of obligations owed to it and only if the company is disabled from acting (such as where there is wrongdoer control of the general meeting) will the law countenance a derivative action. If it is not so disabled the proper plaintiff rule provides that a derivative action cannot be brought. The wrongdoer control requirement is not, as it is sometimes presented, a procedural appendage to the proper plaintiff rule. It is the substantive product of this elemental rule. If the proper plaintiff rule as a substantive rule of law survives the enactment of Part 11, then the requirement to

${ }^{1}$ See D. Kershaw, Company Law in Context: Text and Materials (1 ${ }^{\text {st }}$ ed, 2009), 551, J; Lowry and A. Reisberg, Pettet's Company Law (3rd eds, 2009), 250.

2 P. Davies, Gower and Davies' Principles of Modern Company Law (8 $8^{\text {th }}$ Edition, 2008) (hereinafter 'Gower and Davies'), 615 (hereinafter 'Gower and Davies').

3 Section 260(3) Companies Act 2006.

${ }^{4}$ D. Lightman, 'Two Aspects of the Statutory Derivative Claim' (2011) Lloyd's Maritime and Commercial Law Quarterly 142.

5 Wishart v Castleford Securities Ltd [2009] CSIH 6 (Inner House); Cinematic Finance Ltd v Ryder \& ors [2010] EWHC 3387; Bamford v Harvey [2012] EWHC 2858 (Ch). 
show wrongdoer control must remain as part of contemporary derivative action law and we must make sense of how it is to be applied consistently with Part 11. Yet this view that wrongdoer control is relevant at all is deeply at odds with today's consensus view that Part 11's objective was to abolish wrongdoer control as a threshold condition to bringing derivative litigation. A view that is also informed by, and rests heavily upon, the Parliamentary debates.

This article foregrounds this tension between the old and the new derivative action rules and explores the strength of the case for the continued application of common law proper plaintiff rule together with its corollary, the wrongdoer control requirement. The article shows that the Act alone can be read either as a clean slate or as a new procedure through which the pre-existing substantive common law position is to be applied. When coupled with canons of statutory interpretation on the relationship between legislation and the prior common law rules there is, based on an interpretation of the Act alone, a bias towards the continuing applicability of the proper plaintiff rule and of the wrongdoer control requirement as a threshold condition.

The widely-held consensus that wrongdoer control as a threshold requirement to bringing derivative litigation has been abolished rests, therefore, upon the admissibility of a particular understanding of the mischief of the Act as well as upon the Rule in Pepper v Hart' and the various ministerial statements that the intention of the Act was to remove the wrongdoer control requirement. However, when this record is filtered through the rules that determine which extra-legislative documents are admissible as either evidence of the mischief addressed by a statute or the intention of Parliament then we are left with an admissible extra-legislative record that does not support the view that the Act abolished either the proper plaintiff rule or the wrongdoer control requirement.

Of course, when one's view of a statute and Parliament's intention is formed by facts that are inadmissible to the interpretative process it is extremely difficult to detach knowledge of these facts from the interpretative process. As Lord Browne-Wilkinson observed in Pepper $v$ Hart. 'having once looked at what was said in Parliament it is difficult to put it out of mind'. ${ }^{7}$ This article argues that if we can manage to put it out of our mind we will see that, unexpectedly, the wrongdoer control requirement is still applicable.

\footnotetext{
${ }^{6}[1993]$ AC 593.

7 Pepper v Hart [1993] AC 593 [117] quoted also by Lord Steyn above n. 116 at 66 when discussing the practical difficulties of separating consideration of the ministerial statements after an exhaustive consideration of the meaning of the statute.
} 


\section{PRE-2006 DERIVATIVE ACTIONS}

\section{A. The Rule in Foss v Harbottle ANd Wrongdoer Control}

In Foss $v$ Harbottle, the foundational derivative action case, Wigram VC held that the derivative litigant had no standing to bring the action. The decision was based on two propositions: first, that the company itself had been wronged and, therefore, only the company through its board and shareholder body could elect to sue; ${ }^{8}$ and second, that it made no sense for the court to entertain an action which could at any subsequent time be ratified and cured by the general meeting. ${ }^{9}$ Both propositions are rooted in the notion that it is for the company as a separate legal person to decide what to do in relation to wrongs to which it has been subject. Wigram VC also held that in the absence of an adequate remedy for a wrong 'the claims of justice would be found superior to any difficulties arising out of technical rules'. He observed further that:

In order for this [derivative action] to be sustained it must be shewn either that there is no such power as I have supposed remaining in the [governing body of proprietors to confirm the unlawful act] $\underline{o r}$, at least, that all means have been resorted to and found ineffectual to set that body in motion (emphasis supplied).

This paragraph suggested two grounds which could justify a derivative action: first, where the shareholder meeting does not have the power to confirm or ratify a wrong as in such a situation the courts' practical concern that its actions could be undermined at any time by shareholder confirmation are no longer relevant; and second, where the corporate organs cannot be set in motion in the company's interests because of some practical barrier to action ${ }^{10}$ or because the organs are controlled by the parties who have allegedly wronged the company. In Attool v Merryweather, Page VC observed in this regard:

If I were to hold that no bill could be filed by shareholders to get rid of the transaction on the ground of the doctrine of Foss $v$. Harbottle, it would be simply impossible to set aside a fraud committed by a director under such

\footnotetext{
8 Wigram VC observed that 'whilst the supreme governing body, the proprietors at a special meeting assembled, retain the power of exercising the functions conferred upon them by the Act of Incorporation, it cannot be competent to individual corporators to sue'. He observed further: 'how then can this court act in a suit constituted as this, if it is to be assumed for the purposes of this argument that the powers of the body of proprietors are still in existence and may lawfully be exercised'.

9 Ibid: 'Whilst the court may be declaring the acts complained of to be void at the suit of the present plaintiffs, who in fact may be the only proprietors who disapprove of them, the governing body of proprietors may defeat the decree by lawfully resolving upon the confirmation of the very acts which are the subject of the suit'.

${ }^{10}$ In Foss $v$ Harbottle one of the claims was that it was not possible to call a shareholder meeting due to the absence of formally appointed directors.
} 
circumstances, as the director obtaining so many shares by fraud would always be able to outvote everybody else. ${ }^{11}$

Accordingly, as James LJ observed in Gray v Lewis, the basic 'rule laid down in Foss $v$ Harbottle' is that: 'where there is a body corporate capable of filing a bill for itself to recover property either from its directors or officers, or from any other person. That corporate body is the proper plaintiff, and the only proper plaintiff. ${ }^{12}$ It is most important to note that although it is typically described as an exception to the rule, ${ }^{13}$ the legal relevance of wrongdoer control arises as the substantive product of the proper plaintiff rule. It is only where the company, through its organs, is '[in] capable' of acting that derivative litigation can be considered at all. ${ }^{14}$ It follows therefore, as was held in Smith $v$ Croft (no.2), ${ }^{15}$ that even where there is wrongdoer control, such control does not permit a derivative action where an independent corporate organ - such as the disinterested shareholder body - makes a litigation decision on behalf of the company.

Ultimately, the question which has to be answered in order to determine whether the rule in Foss $v$ Harbottle applies to prevent a minority shareholder seeking relief as plaintiff for the benefit of the company is: 'Is the plaintiff being improperly prevented from bringing these proceedings on behalf of the company?' If it is an expression of the corporate will of the company by an appropriate independent organ that is preventing the plaintiff from prosecuting the action, he is not improperly but properly prevented and so the answer to the question is 'No'. ${ }^{16}$

Accordingly, in Barrett $v$ Duckett ${ }^{7}$ the availability (and good sense) of placing the company in liquidation, which would place corporate power in the hands of an independent liquidator, meant that there was no longer wrongdoer control. For Lawrence Collins J (as he then was) In Konamaneni v Rolls-Royce Industrial Power (India) $L t d^{18}$ such an alternative remedy was 'not an independent bar to a derivative

11 As the Court of Appeal in Prudential Assurance v Newman observed: 'the reason [for the wrongdoer control rule] is that [if the derivative litigant were denied the right to sue] their grievance could never reach the court because the wrongdoers themselves, being in control, would not allow the company to sue'. [1982] 1 ALL ER 354, 358.

12 (1873) LR 8 Ch. App. 1035 (emphasis added). See, also, Russell v Wakefield Waterworks Company (1875) L.R. 20 Eq. 474 per Jessel M.R and, more recently, Prudential Assurance Co. Ltd v Newman (CA) approving of this statement.

${ }^{13}$ See Russell v Wakefield Waterworks Company, ibid, for an early example.

14 Note that the article will often refer only to the wrongdoer control requirement rather than general meeting incapability. It is clear that wrongdoer control is only one, although the most prevalent, example of general meeting incapability. Where the article refers only to wrongdoer control it is used as shorthand for general meeting incapability.

15 [1988] Ch 114.

16 Ibid 185.

17 [1995] 1 BCLC 243.

18 [2002] 1 BCLC 336. 
action, but simply an example of a case where there will be no relevant wrongdoer control'.

At common law derivative actions can only be brought in relation to certain wrongs which, disloyally, serve the directors' personal interests. This category of wrongs, often referred to in the cases as 'fraud', encompass breaches of duty which result in loss for the company and gain for the breaching director. In a classic statement of the rule in Burland v Earle, the Privy Council observed that the exception was applicable in relation to wrongs of a 'fraudulent character' where 'the majority are endeavouring directly or indirectly to appropriate to themselves money, property, or advantages which belong to the company, or in which the other shareholders are entitled to participate'. ${ }^{19}$ Such wrongs are often said to be non-ratifiable wrongs. As noted above, Foss also viewed the inability to ratify as a consideration that would support the bringing of a derivative action because in such circumstances there would be no concern that court action could be undermined by shareholder ratification.

But what wrongs are not ratifiable in English law? Commentators ${ }^{20}$ and judges $^{21}$ have long complained about the absence of clarity in relation to what amounts to a non-ratifiable wrong. The reason for this is that in English law, outside of an ultra vires or illegal act such as the giving of unlawful financial assistance, there is no such category, if such category is constituted solely by the character of the wrong. ${ }^{22}$ Although the proposition that there is such a category has garnered academic support over the years ${ }^{23}$ it is a proposition unfounded on authority. ${ }^{24}$ It is a category of wrongs that has been unable to specify which wrongs fall within it. If close attention is paid to the cases which are said to stand for specific non-ratifiable wrongs, most importantly Cook $v$ Deeks where directors appropriated for themselves a corporate opportunity, we see that the reason that the general meeting could not ratify the wrong was that the general meeting was controlled by the wrongdoing directors, and to allow ratification would therefore

19 [1902] AC 83. Vinelott J in Prudential Assurance v Newman [1980] 2 All ER 841 questioned the extent to which Burland $v$ Earle actually considered there to be a wrong-based restriction on the bringing of a derivative action.

${ }^{20}$ Gower and Davies (8 $8^{\text {th }}$ eds) 588.

21 Airey v Cordell at [2006] EWHC 2728 at [44].

22 See S. Worthington, 'Corporate Governance: remedying and ratifying directors' breaches' (2000) 116 LQR 638 rejecting the ratifiable / non-ratifiable distinction. Support for this also position is found in Vinelott J's first instance judgment in Prudential Assurance v Newman [1980] 2 All ER 841.

${ }^{23}$ See, for example, K. Wedderburn 'Derivative Actions and Foss v Harbottle' (1981) 44 MLR 202 where Lord Wedderburn argues in relation to Cook v Deeks [1916] 1 A.C. 83, 93 (incorrectly in this author's view - see further below) that 'the basis of the decision was the nature of the misappropriation, not the fact that the directors voted as shareholders in the fruitless attempt to ratify the wrong' (emphasis in original).

${ }^{24}$ Limited support is available from Kaye v Croydon Tramways Company [1898] 1 Ch 358 where Vaughan Williams LJ observed 'that there are matters which are intra vires, but yet are of such a character that the majority cannot bind the minority, even though the notice might itself be in due form' (emphasis supplied); although no attempt is made to detail such matters. Support can also be found in statements that assume the existence of such a category without regard to authority that establishes that category. See for example Lord Millett's recent decision in Waddington v Chan [2009] 2 BCLC 82. The 2006 Act (section $239(7)$ ) explicitly retains 'any rule of law as to acts that are incapable of being ratified by the company'. Such provision should be read as being applicable to ultra vires acts (internally) and unlawful acts such as unlawful financial assistance. 
have been to 'allow the majority to oppress the minority'. ${ }^{25}$ That is, the characteristic of non-ratifiability is not related to the nature of the wrong alone but, in addition, to the control of the general meeting by the wrongdoer. An important corollary of this position is that a wrong that could not be ratified by a meeting carried by the wrongdoer could be ratified by a meeting in which his votes and/or influence do not carry the meeting.

This is not to say that the nature of the wrong is irrelevant. The authorities stand for the proposition that actions that are disloyal and directly benefit the wrongdoer at the expense of the company cannot be ratified where the votes of the wrongdoer carry the meeting. A breach of duty that does not both benefit the director personally and result in a loss for the company could, therefore, be ratified by a vote carried by the wrongdoing director's votes. ${ }^{26}$ It is noteworthy in this regard that in Burland $v$ Earle the 'fraudulent character' restriction is a product of the holding that a derivative action cannot be brought where it is 'capable of being confirmed by the majority' (emphasis supplied). Such a position is consistent with the proper plaintiff rule: in relation to such wrongs, even where there is wrongdoer control, the company is capable of acting.

Around 1950, the 'fraud' and wrongdoer control restrictions were grouped into an exception to the rule in Foss $v$ Harbottle known as the fraud on the minority' exception. ${ }^{27}$ Prior to 1950 the cases did not refer to the 'fraud on the minority' exception. Today, it would typically be said the fraud on the minority exception involves two propositions: first, the wrong must be a non-ratifiable 28 wrong or a wrong that falls within a category of 'fraud'; and second there must be wrongdoer control of the general meeting. ${ }^{29}$ Through the lens of this exception, wrongdoer control is understood as part of the fraud on the minority exception and, typically, subsequent to the determination of 'fraud' although in many

${ }_{25}$ Cook v Deeks [1916] 1 A.C. 554, 564 where the Privy Council also observed 'if directors have acquired for themselves property or rights which they must be regarded as holding on behalf of the company, a resolution that the rights of the company should be disregarded in the matter would amount to forfeiting the interest and property of the minority of shareholders in favour of the majority, and that by the votes of those who are interested in securing the property for themselves. Such use of voting power has never been sanctioned by the Courts' (emphasis added). By implication, such a resolution would be effective if it was not passed by 'votes of those who are interested in securing the property for themselves'.

${ }^{26}$ North West Transportation Company Limited v Beatty (1887) 12 App Cas 589; Regal (Hastings) v Gulliver [1942] 1 All ER 378.

27 Edward v Halliwell [1950] 2 All E.R. Prior to 1950 the cases did not refer to the 'fraud on the minority' exception. See K.W. Wedderburn, 'Shareholders Rights and the Rule in Foss v Harbottle' (1957) CLJ 194203-204; Edward v Halliwell [1950] 2 All E.R.

${ }^{28}$ Note that if the term non-ratifiable wrong is used then wrongdoer control is applied twice as wrongdoer control is part of the determination of when the wrong is not ratifiable.

${ }^{29}$ See Gower, $6^{\text {th }}$ eds 673-674. 
important early cases wrongdoer control was the first, ${ }^{30}$ and in some the only, consideration. ${ }^{31}$

The language and order of rule and exception misleads us into seeing all the rules that form 'the exception' as separable and distinct from the proper plaintiff rule. Through this lens, the proper plaintiff rule becomes merely a rebuttable presumption $^{32}$ and it follows from this that the substantive rules which determine if the presumption can be rebutted - including wrongdoer control - can be abolished or amended whilst leaving the proper plaintiff rule intact. ${ }^{33}$ This is incorrect and not supported by authority. The proper plaintiff rule as set forth in Foss $v$ Harbottle and its progeny is a substantive rule of law ${ }^{34}$ that is umbilically connected to the wrongdoer control rule, which is merely one example of a circumstance in which the company is not capable of acting. The common law proper plaintiff rule provides that where the corporate organs are 'capable' of acting in the corporate interest there can be no derivative action. Only when those organs are incapacitated, by, for example, wrongdoer control of the general meeting, can such an action be brought. Accordingly, if one were to allow derivative actions in the absence of either wrongdoer control or some other form of general meeting incapability then the common law proper plaintiff rule would no longer be applicable.

30 Burland v Earle [1902] AC 83 (PC). See also, Russell v Wakefield Waterworks Company (1875) L.R. 20 Eq. 474. More recent courts were also equivocal about the relationship between wrongdoer control and proper plaintiff rule and the fraud on the minority exception. See, for example, Barrett v Duckett [1995] 1 BCLC 243 , where the wrongdoer control exception is presented as a stand alone exception.

31 Law Commission Consultation Document on Shareholder Remedies, paras 4.12-4.16. For this order of presentation see Gower and Davies (6 $6^{\text {th }}$ Edition); Kershaw, above n. 1 at 549 and J. Lowry and A. Dignam, Company Law (2nd eds, OUP 2003). The case typically cited for this view of the fraud on the minority exception and the position of wrongdoer control is Edwards v Halliwell [1950] 2 All ER 1064 where Jenkins LJ observed that: 'it has been further pointed out that where what has been done amounts to what is generally called in these cases a fraud on the minority and the wrongdoers are themselves in control of the company, the rule is relaxed in favour of the aggrieved minority' (restated in the leading case of Prudential Assurance v Newman [1982] 1 All ER 354 observing that: 'there is an exception to the rule where what has been done amounts to fraud and the wrongdoers are themselves in control of the company.' The Law Commission observes that the rules 'was authoritatively stated by Jenkins LJ in Edwards v Halliwell (para 4.35, Consultation Document).

32 Jenkins LJ in Edwards v Halliwell, ibid observes that 'the proper plaintiff in an action in respect of a wrong alleged to be done to a corporation is, prima facie, the corporation' (emphasis added).

${ }^{33}$ See the presentation of the rules and exceptions in Prudential Assurance Co Ltd v Newman Industries Ltd (no.2) [1982] Ch 204 where the rules and exceptions are listed (1) - (5) with wrongdoer control only mentioned in (5). Deleting 5 in this presentation does not affect (1).

34 Konamaneni and others $v$ Rolls-Royce Industrial Power (India) Ltd [2002] 1 BCLC 336 where Lawrence Collins J (as he then was) observed that 'Gower ( $\mathrm{p}$ 665) goes as far as to say that the basic rule in Foss $v$ Harbottle is part of the law of civil procedure, although it is not easy to see how the basic rule stated in Prudential Assurance Co Ltd v Newman Industries Ltd (No 2) [1982] 1 All ER 354 at 357, [1982] Ch 204 at 210 that 'A cannot, as a general rule, bring an action against $\mathrm{B}$ to recover damages or secure other relief on behalf of $\mathrm{C}$ for an injury done by $\mathrm{B}$ to $\mathrm{C}^{\prime}$ can be regarded as a merely procedural rule'. 


\section{B. Post-Wrongdoer Control / Fraud on the Minority Hurdles}

As we have seen, underpinning the common law derivative action rules is an understanding that in the absence of an 'independent' general meeting there is no corporate body capable of acting truly independently in the corporate interest in relation to the litigation decision against directors. In such circumstances an exception is made to the rule that the company is the only possible plaintiff. However, although allowing an individual shareholder to bring an action addresses the independence problem it does not provide any guarantee that the individual shareholder's decision to bring the action, and her management of the action, will be in the corporate interest. In Prudential Assurance Co. $v$ Newman Industries Ltd ${ }^{35}$ the Court of Appeal held that whether a derivative action could be brought must be dealt with at a preliminary hearing at which the court would determine: (i) whether the company was 'prima facie [...] entitled to the relief claimed'; and (ii) whether 'prima facie' 'the action [fell] within the proper boundaries of the exception to the rule in Foss $v$ Harbottle. The proper boundaries of the exception were not set forth in the Prudential judgment with any precision, however, it is clear from the case a court should first, establish whether the company is incapable of acting for itself and second, determine whether it is in the corporate interest to allow such litigation to continue. In Prudential, of particular concern was the fact that an independent and disinterested board had determined that the action 'would do more harm than good' and could kill the company with kindness.

In subsequent cases a set of common law rules emerged which, in different guises, assessed whether the proposed derivative action was in the corporate interest. It is important to note that these rules are distinct from the threshold and elemental requirement that a derivative action is simply unavailable in the absence of general meeting incapacity, resulting from wrongdoer control or otherwise. These rules assist the court in determining whether a derivative action, which is formally available, is in the company's interest and whether the derivative litigant is the appropriate person to bring the action. As Lawton LJ observed in Nurcombe v Nurcombe: 36

Since the procedural device has evolved so that justice can be done for the benefit of the company, whoever comes forward to start the proceedings must be doing so for the benefit of the company and not for some other purpose. It follows that the court has to satisfy itself that the person coming forward is the proper person to do so.

The question of whether a derivative litigant is acting in the corporate interest could be approached subjectively or objectively. A subjective approach looks to the bona fides of the party and asks: does that party think he is acting in the

35 [1982] 1 All ER 354.

36 [1985] 1 ALL ER 65. 
corporate interest by bringing the derivative litigation? This approach looks for any evidence that would suggest that the party has a collateral, non-corporate objective which she is furthering through the derivative litigation. An objective approach asks whether, according to a benchmark determined by reference to a hypothetical actor such as a reasonable director, the action is actually in the corporate interest.

The pre-2006 Act common law rules on whether it is in the company's interests to bring derivative litigation have gravitated from a subjective approach to both and a subjective and an objective approach. Relying upon Nurcombe $v$ Nurcombe, in 1995 the Court of Appeal in Barrett v Ducket ${ }^{7}$ held that the action will only be allowed to proceed if it is brought 'bona fide for the benefit of the company' and not for any ';ulterior purpose'. In Barrett the action was not allowed to proceed because, amongst others, although the actions themselves fell within the wrongdoer control exception, ${ }^{38}$ the shareholder was held to be motivated by a personal grudge against the director, who was the ex-husband of the shareholder's daughter.

The rules on permission to continue an action did not require that the action be objectively in the corporate interest until shortly before the enactment of 2006 Act. Arguably, prior to this date there was the functional equivalent of an objective test to continue the action because obtaining an indemnification costs order whereby the court orders the company to cover the derivative litigant's costsrequired a determination that in the court's view 'it would have been reasonable for an independent board exercising the standard of care which a prudent business man would exercise in his own affairs to continue the action to judgment'. ${ }^{39}$ In the absence of an indemnification order few litigants would have taken the risk of continuing to judgment where they would bear all legal costs if unsuccessful but would gain only a proportionate indirect benefit as a shareholder if successful. In Mumbray $v$ Lapper 40 and Airey $v$ Cordell ${ }^{41}$ this objective prerequisite to obtaining an indemnity order was extended to the question of whether a derivative action would be permitted to continue. Warren J in Airey $v$ Cordell held that 'the correct test for allowing the action to continue and for costs too is to be the independent board test' which he understood to involve asking whether the decision is one 'which a reasonable board could take'.

A third approach to determining corporate interest is to rely upon the views of the independent members of the corporate organs. For example, in Prudential Assurance for the Court of Appeal the fact that the disinterested board had elected not to pursue the litigation would have been a weighty consideration for a court

\footnotetext{
37 [1995] 1 BCLC 243.

38 In this case the claimants and defendant both held $50 \%$ of the shares in the company and therefore although there was no wrongdoer control the general meeting was disabled. There was not discussion of whether the wrongs fell within the fraud category, however, it appears clear on the facts of the case that they did.

39 Wallersteiner v Moir (No.2) [1975] 2 WLR 389 per Buckley LJ.

40 [2005] EWHC 1152.

${ }^{41}$ [2006] EWHC 2728.
} 
considering a preliminary application. For Knox J in Smith $v$ Croft (No.2) 'the views of the rest of the minority as to the advisability of the prosecution' were relevant to the determination of whether the litigation 'will be more productive of harm than good'. ${ }^{2}$

Finally, although a source of some contention, it seems that at common law the courts will have regard to the availability of an alternative remedy in making their decision, even though the alternative remedy does not itself have a direct effect on wrongdoer control. In Barrett $v$ Duckett 43 for example, the Court of Appeal appeared to accept that availability of an unfair prejudice action was relevant to their determination of whether or not to allow the litigation to proceed.

\section{THE NEW DERIVATIVE CLAIM}

The derivative claim rules set forth in Part 11 of the Companies Act 2006 do not explicitly purport to abolish or supersede the Rule in Foss $v$ Harbottle. The Act provides that a derivative claim can only be brought in accordance with the Act ${ }^{44}$ and removes any wrong-based restriction by providing that a claim may be brought in relation to any breach of duty, negligence, default or breach of trust by the director. ${ }^{45}$ The 'fraud' precondition to the 'fraud on the minority' exception has clearly, therefore, been abolished. This in itself is a notable change, which increases the exposure of directors to liability for breaches of the duty of care.

Once an action has been commenced the derivative claimant must apply to court for permission to continue the litigation just as under the old rules a litigant had to obtain permission to bring a derivative action in a preliminary hearing. The Act provides for two stages of the permission process. At the first stage the court must determine on the evidence filed with the application whether there is a 'prima facie case for giving permission'. In the second stage, where the permission decision is made, evidence from the company will also typically be admissible. 46 The Act sets forth criteria which in some instances determine the court's decision and in others provide guidelines for courts to consider when exercising discretion about whether the claim should continue. Pursuant to section 263(2) of the Act the court must discontinue the claim when the shareholder body has ratified or authorised the breach. In such circumstances there is no claim, the breach having been cured. Section 263(2) also provides that permission must be refused if the court is satisfied that a person acting in accordance with section 172 (which is the duty to promote the success of the company) would not seek to continue the claim'.

42 [1987] 3 All ER 909, 957.

43 [1995] 1 BCLC 243.

${ }^{44}$ Section 260(2) Companies Act 2006.

45 Section 260(3) Companies Act 2006.

46 262(3) and (4) Companies Act 2006. 
If the breach has not been ratified or authorised and the court is not of the view that a hypothetical director would not seek to discontinue the claim, then the Act provides the court with discretion as to whether such an action should be permitted to continue. The Act sets forth seven non-exclusive factors for the court to consider:47 the good faith of the derivative litigant; 'the importance that a person acting in accordance with section 172 would attach to continuing' the claim; whether the proposed action is likely to be authorised, or the alleged breach is likely to be ratified; whether the company has elected not to pursue the claim; whether the member has an alternative personal remedy; and the views of the disinterested members on the derivative litigation.

Nowhere in the Act is the proper plaintiff rule or its corollary, wrongdoer control, mentioned as a consideration or as a precondition to being able to bring a derivative claim. Given the prominence of wrongdoer control to the common law rules, the Act's silence in this regard is widely thought to have abolished this requirement. Professor Davies observes, for example, that Foss v Harbottle is thus consigned to the dustbin'. ${ }^{48}$ Arad Reisberg observes that 'the previous rules in Foss and other cases will not be directly relevant' and 'the claimant does not need to show wrongdoer control'. ${ }^{49}$ This author has previously observed that 'the new statutory derivative claim in effect overrules the Rule in Foss v Harbottle ${ }^{50}$ In Iesini v Westrip Holdings Ltd ${ }^{51}$ Lewison J observed that 'the new code has replaced the common law derivative action'.52 For the Inner House in Wishart v Castlecroft Securities $L t d,{ }^{53}$ wrongdoer control was not 'repeated' in the Act and, therefore, is no longer part of derivative action law. For Roth J in Bamford v Harvey, following the Inner House in Wishart, 54 'wrongdoer control is not an absolute condition for a derivative claim'.

This stance on the relationship between the prior common law rules and Part 11 is primarily based upon statutory silence and the view that the Act was intended

47 Sections 263(3) and (4) Companies Act 2006.

48 Gower and Davies ( $8^{\text {th }}$ eds) 615. Gower and Davies also observe that 'under the statutory procedure permission to continue the litigation can be granted by the court even if the alleged wrongdoers are not in control of the general meeting'. See also Kershaw, above n.1 at 551 observing that the new procedure represent 'a profound change in UK company law'.

49 A. Reisberg, 'Derivative Claims Under the Companies Act 2006: Much Ado About Nothing" in J. Armour \& J. Payne (eds) Rationality in Company Law: Essays in Honour of D.D. Prentice (Hart Publishing, 2009) at [] and note 224. See also A. Keay and J. Loughrey, 'Something Old, Something New, Something Borrowed: An Analysis of the New Derivative Action under the Companies Act 2006' (2008) LQR 469.

${ }^{50}$ D. Kershaw, Company Law in Context: Text and Materials (1 ${ }^{\text {st }}$ eds, OUP, 2009) 551.

51 [2009] EWHC 2526 at [73].

52 Apart from the cases considered directly in this Part, the cases to date dealing with claims under Part 11 have largely not considered the status of the proper plaintiff rule and the wrongdoer control requirement under the Act. In most of these cases the alleged wrongdoers controlled the general meeting. This is clearly the case in Parry v Bartlett [2011] EWHC 3146 (Ch); Franbar Holdings Lts v Patel [2008] EWHC 1534; Kiani v Cooper [2010] 2 BCLC 427; Stainer v Lee [2010] ALL ER (D) 56; Kleanthous v Paphitis [2011] EWHC 2287. The position is unclear from the facts in Iesini v Westrip Holdings Ltd [2010] All ER (D) 108 and Mission Capital plc v Sinclair [2008] All ER (D) 225.

53 [2009] CSIH 65.

54 [2012] EWHC 2858 (Ch). 
to implement the Law Commission's proposals on Shareholder Remedies ${ }^{55}$ which recommended the abolition of the fraud on the minority exception - as well as, for the academic commentary in particular, upon certain ministerial statements about the new procedure which are presumed to be admissible evidence of Parliamentary intent. ${ }^{56}$ We consider the mischief addressed by the Act and the admissibility of these ministerial statements below in Part V of this article. Placing these materials and their admissibility to one side, the Act itself allows of an alternative, and largely unexplored, interpretation of the relationship between Part 11 and the common law. A relationship of continuity and codification, not abolition and a new beginning. A relationship which is suggested in different ways by several recent judgments. It is also suggested by other evidence of mischief and those same ministerial statements.

Consider, for example, Cinematic Finance $v$ Ryder. ${ }^{57}$ In this unusual case in which the majority shareholder attempted, unsuccessfully, to bring a derivative action, the court recognised that 'proceedings for a derivative claim are now comprehensively governed by the Act'. However, in his judgment Roth J also observes that Part 11 has not dislodged the proper plaintiff rule as the fundamental principle of English derivative action law. Roth $\mathrm{J}$ quotes from Prudential Assurance Company Limited v Newman Industries' explanation of the 'elementary'58 proper plaintiff principle, cites the Law Commission's view that the proper plaintiff is a guiding principle of the law, and observes that:

In my judgment the Act is not seeking to change the basic rule that a claim that lies in a company can be pursued only by the company or to disturb the fundamental distinction between a company and its shareholders. There is nothing to suggest that the Act intended such a radical reversal of longstanding and fundamental principles.

This view echoes the position set forth in the Explanatory Notes to the Company Law Reform Bill, considered in greater depth below, which observed that: 'the [new derivative claim] clauses do not formulate a substantive rule to replace the rule in Foss v Harbottle. Roth J affirmed the view set forth in Cinematic Finance in the recent case of Bamford $v$ Harvey. ${ }^{59}$ If Roth $\mathrm{J}$ is correct that the proper plaintiff rule survives the 2006 Act's reforms we need to think carefully about the substantive content of such a proper plaintiff rule and its relationship to wrongdoer control.

In Bamford $v$ Harvey itself Roth J concluded that it is possible to maintain the proper plaintiff rule as a 'guiding principle', and yet to abolish wrongdoer control as a threshold condition. Had wrongdoer control been retained, he observed, it

\footnotetext{
${ }^{55}$ Law Commission, Shareholder Remedies (Final Report). See, for example, Reisberg above n 49. See Wishart ibid, at [3] and [39].

56 See Cabrelli below n. 64 and Reisberg, above n. 49.

57 [2010] EWHC 3387.

58 [1982]1 Ch 204 at 210[ D-E].

59 [2012] EWHC 2858.
} 
would have been specified in section 263(2). The problem with this conclusion, however, is that it is logically inconsistent with the holding in Cinematic Finance, affirmed in Bamford v Harvey, that Part 11 does not alter the 'elemental' and 'basic' proper plaintiff rule. This is because, as we observed above, at common law wrongdoer control is not a detachable part of the proper plaintiff rule, but inextricably linked to it. The rule provides that no shareholder can bring an action if the company, operating though its general meeting, is 'capable' of doing so. It follows from this rule that in the absence of wrongdoer control, or some other unusual circumstance disabling the general meeting, the corporate organs retain sole authority to make the litigation decision. There can be no recourse to derivative litigation in such circumstances. If a derivative action can be brought where the general meeting is capable of doing so, then the proper plaintiff rule, as a 'longstanding and fundamental principle' of the common law, is no longer part of English derivative action law.

Roth $\mathrm{J}$ is aware of the relationship between the proper plaintiff rule and whether the company is capable of acting, which is why, although he holds that wrongdoer control is not a threshold condition, he holds that that is still a relevant consideration in exercising the permission discretion. In doing so he appears to elevate wrongdoer control to something approaching a threshold condition. ${ }^{60} \mathrm{We}$ will consider this conclusion in more detail below in Part VI. For now, note first, Roth J's understanding of the relationship between the proper plaintiff rule, corporate capability and wrongdoer control, and second, that his rejection of wrongdoer control as a threshold condition is driven, in part, by a view of section 263(2) which is shown below to be incorrect.

Uncertainty surrounding the status of proper plaintiff rule and wrongdoer control is present in other post-Act derivative claim judgments. In Wishart $v$ Castlecroft Securities, a Scottish case, at first instance Lord Glennie provided that wrongdoer control was a threshold condition to be considered at stage one of the permission process, in the absence of which there would be no need to consider any of the factors set forth in section $263^{61}$ of the Act. Such a requirement was, he observed, 'implicit in the nature of derivative proceedings' which is consistent with the view that the proper plaintiff rule remains applicable and that its corollary is wrongdoer control.62 On Appeal, Lord Reed in the Inner House reversed this holding observing that 'one of the objects of the 2006 Act was to introduce more flexible criteria than the former "fraud on the minority" exception to the rule in

${ }^{60}$ For Roth J as for Judge Pelling QC in Stimpson, wrongdoer control can be taken into account simply through the exercise of the judge's section 263(3) discretion. Section 263(3) provides for a non-exhaustive list of considerations. In refusing permission to continue the action he appears to concludes that although wrongdoer control is not a threshold condition the absence of wrongdoer control will typically result in permission being refused: "It is not elevating "wrongdoer control" to a preclusive condition for the court to hold that when proceedings can clearly be brought in the name of the company and there is no objection raised on that ground, they should be brought in the name of the company'.

61 The Act provides a separate but substantively identical procedure in Scottish cases. The '263 criteria' are set forth in section 268 .

62 [2010] B.C.C. 161, [27]. Lord Glennie also observed that the statutory rules 'are clearly informed by the prior English practice developed before the Act in case law and in Rules of Court' at [24]. 
Foss $v$ Harbottle' and that 'the requirement of "wrongdoer control" is not repeated in section [263]'. ${ }^{63}$ The Inner House's conclusion that the wrongdoer control requirement has been abolished was the product of its absence from the Act coupled with a view that the mischief of the Act was based on the Law Commission's view of the problems associated with the common law, and that the Act implemented the Commission's recommendation to replace the 'fraud on the minority exception'.64 The Inner House's view of the relationship between the Commission's report and the Act was adopted by Roth J in Bamford $v$ Harvey. But it is a view, which as we shall see below, is contestable.

In Stimpson v Southern Private Landlords Association ${ }^{65}$ the Court briefly considered the status of wrongdoer control. Judge Pelling QC in response to a submission that wrongdoer control was no longer relevant indicated that it would be a relevant consideration. He observed that:

Under the old law if there was no wrongdoer control of the company, permission would be refused for the obvious reason that in the circumstances there was no need for derivative proceedings to be commenced. It was submitted on behalf of the Claimant that these principles do not appear in the statute and therefore are no longer relevant. I am doubtful if that is correct.

For Judge Pelling QC the fact that there was no wrongdoer control in this case was 'at least a powerful [consideration] that negatives the giving of permission and may be overwhelming'. But for Judge Pelling QC wrongdoer control is not a presection 263 threshold consideration, rather, as it was for Roth J in Bamford v Harvey, it is an additional consideration which may be considered by the court by virtue of the non-exclusive nature of section 263(3).

These cases raise the question of the post-Act status of the proper plaintiff rule: whether it is possible and correct to read the Act as simply providing a clearer and more accessible procedure for the application of the common law rules, including an absolute requirement to show wrongdoer control or other corporate incapability; and, if not, in what way is it possible to effectively and coherently take account of the proper plaintiff rule through Part 11. Importantly, the exploration of this question should not be truncated by the rejection in Wishart and in Bamford of a wrongdoer control threshold condition. Wishart, followed in Bamford, was

${ }^{63} \mathrm{Ibid}[38]$.

${ }^{64}$ Ibid [3] observing that 'the recommendations of the Law Commission formed the basis of [...] a new legislative framework for derivative claims in England and Wales'. In the Law Commission's Final Report on Shareholder Remedies at [1.13] the Commission observes that 'more modern, flexible and accessible criteria for leave to bring a derivative action would replace the current "fraud on the minority" exception'. See also D. Cabrelli, 'Statutory Derivative Proceedings: The View from the Inner House' (2010) 14 The Edinburgh Law Review 116 arguing that the Inner House's rejection of Lord Glennie's position on wrongdoer control 'was correct $[\ldots]$ for the reasons previously advanced by this author, namely that Parliament had intended to remove the requirement to establish wrongdoer control which existed at common law'.

65 [2009] EWHC 2072 [46]. 
based upon a flawed understanding of the status of the Commission report as evidence of the mischief at which the statute was aimed and a failure to explore whether such a threshold condition could be compatible with Part 11 and in particular its omission from section 263(2). We explore these issues below. The starting point must be with the Act itself.

\section{WRONGDOER CONTROL: IN SEARCH OF LEGISLATIVE IMPLICATION}

What is the best reading of Part 11 of the Act? Does it abolish the Rule in Foss $v$ Harbottle and the corporate incapability / wrongdoer control requirement? Or in the alternative can it be read persuasively as merely the provision of a codified procedure for the application of the pre-existing common law rules, including both the wrongdoer control requirement and the corporate interest considerations? In the first instance we must engage with this question without any regard to anything we might think 'we know' about the mischief addressed by the Act or what Parliament intended as evidenced by the statements of ministers during the passing of the Bill. The later only becomes relevant where the statutory language is deemed to be ambiguous or obscure. The former, although part of the context of the interpretative process, in this instance provide limited assistance. At best, as we consider in detail below, analysis of the documents that could identify the mischief addressed by the Act suggest a bias in favour of continuity.

\section{A. GenERAL INFERENCES}

The enactment of a statute that addresses activity subject to common law rules does not replace those common law rules unless such rules are abrogated expressly or impliedly by the statute. Lord Browne-Wilkinson in $R v$ Secretary of State for the Home Department, Ex Parte Pierson, made the following observations in this regard:

It is well established that Parliament does not legislate in a vacuum: statutes are drafted on the basis that the ordinary rules and principles of the common law will apply to the express statutory provisions. As a result, Parliament is presumed not to have intended to change the common law unless it has clearly indicated such intention either expressly or by necessary implication. ${ }^{66}$

66 [1998] AC 539. Maxwell on the Interpretation of Statutes (12th edn), at 116 cited by Lord Brown-Wilkinson observes that: 'it is presumed that the legislature does not intend to make any change in the existing law beyond that which is expressly stated in, or follows by necessary implication from, the language of the statute in question.' See also, Beattie v Royal Bank of Scotland [2003] SCLR 352, [35] for an example of relying on this presumption to find that a statute does not alter the prior common law position which would have amounted to 'a significant change in existing (and longstanding) law'. For earlier authority see further Harrison v Tew [1990] 2 AC 523, 536 observing that 'the common law can co-exist with a statutory provision with which it is not inconsistent' and approving of the observation of Coke's Institutes of the 
As the Companies Act 2006 makes no express statement about the status of the common law rules, if the common law proper plaintiff rule and wrongdoer control requirement have been abolished then we must identify such a change in the law by 'necessary implication'. In the context of the interpretation of statutes creating criminal offences and the presumption that mens rea is required for conviction of a criminal offence, Lord Nicholls in B (a minor) v DPP observed that "necessary implication" connotes an implication which is compellingly clear. ${ }^{27}$ This view has been adopted outside of the criminal law context. ${ }^{68}$ Lord Nicholls noted further that such implication could be found in the language used in the statute and the mischief of the statute. In this section we focus only on the language of the statute $^{69}$ and return to the mischief in Part V.

A strong argument for the implied abrogation of the proper plaintiff rule is that by providing that derivative claims can 'only be brought' in accordance with Part $11^{70}$ that the Act replaces the common law rules, leaving the Act's provisions as the exclusive point of reference for considering the permissibility of derivative claims. This is the position taken by Lewison J in Iesini $v$ Westrip Holdings. ${ }^{71}$ This leaves no room for the continuing application of the proper plaintiff rule as it is not referred to in Part 11.

A counterargument is that the Act simply provides a procedure for derivative claims that are capable of being 'brought'. That is, it codifies only those common law rules that apply once a determination that the general meeting is incapable of acting has been made. If the general meeting is capable of acting, the claim cannot be 'brought' at all. Under the pre-Act position, pursuant to the applicable Civil Procedure Rules claimants were required 'to apply to the court for permission to continue the claim'. ${ }^{72}$ Whilst this is very similar to the approach taken by the Act, these rules did not specify the considerations courts were required to take into account. In practice, on this application the courts would consider both compliance with the threshold company incapability requirement as well as the common law corporate interest factors considered in Part II above. ${ }^{73}$ Part 11, by way of contrast with the courts' pre-Act approach, makes no explicit provision for any such procedural threshold determination by the court. This suggests that the

Laws of England (1817) 200 that 'it is a maxim of the common law, that a statute made in the affirmative does not take away the common law'. See also Greene v Associated Newspapers Ltd [2004] EWCA Civ 1462 (CA) at [62] observing that 'first principles in statutory interpretation would also rule out the dismantling of judge made law by stealth (in the absence of necessary implication)'.

67 [2000] 2 AC 238, 464.

68 See R (on the application of Morgan Grenfell)v Special Commissioner [2001] EWCA Civ 239 (CA) at [15] holding that 'the concept of necessary implication connotes an implication which is compellingly clear' in the context of whether the Taxes Management Act 1970 overrode legal professional privilege.

69 Note that for Maxwell in The Interpretation of Statutes above n. 66 cited by Lord Browne-Wilkinson 'the necessary implication' must be found in the statutory language alone.

70 Section 260(2) Companies Act 2006

71 See text to note 52 .

72 CPR 19.9(3).

73 Barrett v Ducket [1995] 1 BCLC 243. 
proper plaintiff rule has been abolished because it would be baffling for the statute to provide for a procedure for derivative claims which presumed that a prior threshold determination must be made in a separate, and not provided for, procedure. Accordingly, unless Part 11 provides a procedural place for the proper plaintiff rule the inference of abolition is compelling.

Lord Glennie's interpretation of the Act in his Outer House ruling in Wishart $v$ Castlecroft Securities ${ }^{74}$ provides for such a place. He holds that the Act makes provision for consideration of corporate incapability through the two stage process. Stage $1^{75}$ he holds should involve consideration of whether there is a prima facie case on the merits and whether there is 'a prima facie case that those responsible those for that Act or omission are or remain in majority control, thus preventing institution of proceedings at the instance of the company'. ${ }^{76}$ On this reading the term 'prima facie case for giving permission' does not simply mean that there is prima facie case based on the permission criteria in section 263 rather it means that in order to move to Stage 2 there must be: (i) a prima facie case on the merits; (ii) a prima facie case of wrongdoer control or another form of corporate incapability; and (iii) a prima facie case that pursuant to the section 263 criteria permission would be granted. A slightly different reading, and one which Lord Glennie may well adhere to, ${ }^{77}$ is that the prima facie determination involves only (i) and (ii). This reading suggests that the phrase 'prima facie case for giving permission' means that in the absence of (i) and (ii) the claim is not capable of being brought derivatively at all and therefore is not one in relation to which the court should consider whether it should 'give permission' in stage 2 of the process.

This understanding of the meaning of 'prima facie case' is derived from the pre-Act case law. The preliminary procedure introduced by Prudential Assurance v $N_{e w m a n}^{78}$ used the term 'prima facie case' to refer to both (1) a prima facie case on the merits and (2) a prima facie case that 'the action falls within the proper boundaries of the exception to the Rule in Foss $v$ Harbottle. ${ }^{79}$ In Airey $v$ Cordell, a case which has been relied upon in post-Act cases to understand other provisions in Part 11,80 relying on this quote Warren $\mathrm{J}$ observed that: 'I note that the reference to prima facie case is in relation to (1) and (2), ${ }^{81}$ Under the pre-Act

${ }^{74}$ Whilst Lord Glennie's judgment was overruled by the Inner House, the Inner House does not engage with this interpretation directly but rather bases their holding on, in their view, the intention of Parliament to implement the Law Commission's recommendations and remove the wrongdoer control requirement.

${ }^{75}$ Note that the Stage 1 and 2 procedure was introduced as an amendment to the Companies Bill in the Lords. See Hansard, 9 May 2006, Column 883 and 889.

${ }^{76}$ [2010] BCC 161, [27]

${ }^{77}$ Lord Glennie did not extend his approach to include (iii) as well.

78 [1982] Ch 204.

${ }^{79}$ Ibid at [222]: 'In our view, whatever may be the properly defined boundaries of the exception to the rule, the plaintiff ought at least to be required before proceeding with his action to establish a prima facie case (i) that the company is entitled to the relief claimed, and (ii) that the action falls within the proper boundaries of the exception to the rule in Foss v. Harbottle.'

${ }^{80}$ See, for example, Iesini v Wetsrip Holdings [2011] 1 BCLC 498 relying on Airey v Cordell [2006] EWHC 2728 in interpreting section 263(2)(a) Companies Act 2006.

${ }^{81}$ [2006] EWHC 2728 [45]. For (1) and (2) see (i) and (ii) ibid. 
process the prima facie case determination applied to both the threshold proper plaintiff/corporate capability determination and the post-incapability considerations outlined in Part II above. Accordingly, if the term 'prima facie case' is being used in the Act as it was used in the prior case law then what Stage 1 includes is a determination of whether there is a prima facie case that the general meeting is incapacitated.

Furthermore, in support of this approach, if Stage 1 does not involve a threshold determination it is difficult to understand what the point of Stage 1 is at all. If a prima facie case involves the presumption that the facts stated are true, and Stage 1 is only designed to consider whether there is a prima facie case based on the section 263 criteria, then Stage 1 will only filter out the most incompetently drafted applications: an application that states the honestly and good faith of the litigant, the existence of a prime facie case on the merits, and asserts the absence of substantive business costs for the company must always move to Stage 2 . Whilst the term prima facie case is meaningful as a proof burden - do the stated facts establish a cause of action - it is inapposite if not meaningless for the types of considerations set forth in section 263.

An alternative argument that Part 11 replaces and abolishes all common law derivative action rules is provided by the fact that in relation to directors' duties which the Act $\operatorname{codifies}^{82}$ for the first time and with some controversy - as the intention was to provide for the continuing applicability of the common law rules the Act explicitly says so. ${ }^{83}$ Part 11 has no such provision, which could be taken to imply that the common law rules do not continue to apply. This is an important consideration given the weight placed on the common law meaning of 'prima facie case' above. Nevertheless, it is readily dismissed. The Act both codifies directors' duties but then makes it clear that the codification is not designed to alter the substance of the case law on which the codification is based. By way of contrast, Part 11 attempts no codification of the proper plaintiff rule it simply, on the above reading, provides a portal for its procedural application through the term 'prima facie case'. On the continuing application of the common law to understand the meaning of Part 11, it is noteworthy that the courts in interpreting other aspects of Part 11 have relied upon pre-Act cases to understand the meaning of the Act's provisions. ${ }^{84}$

\section{B. SPECIFIC INFERENCES: WRONGDOER CONTROL AND SECTION 263}

If there is no conclusive general inference from Part 11 that the proper plaintiff rule and its corollary wrongdoer control have been abolished, is such an inference

82 See sections 170-177 Companies Act 2006.

83 Section 170(3) Companies Act 2006 provides that the duties are 'based' on the common law rules. Section 170(4) provides that the codified general duties in section 171-177 shall be interpreted in accordance with the prior common law rules.

84 See, for example, Iesini v Wetsrip Holdings [2011] 1 BCLC 498 relying on Airey v Cordell [2006] EWHC 2728; and Franbar Holdings v Patel [2008] EWHC 1534 relying on Barrett v Duckett [1995] 1 BCLC 243. 
available from the inconsistency of any of the section 263 considerations with the continuing application of such a rule?

Section 263(2) provides that permission to continue the claim must not be granted if the unlawful act has been ratified or authorised or if the action is one that a person acting in accordance with section 172 would not seek to continue. If the Act had intended to retain wrongdoer control as a bar to the bringing of an action wouldn't the legislature have placed it in section 263(2) with the other bars? As noted above, Roth $\mathrm{J}$ in Bamford $v$ Harvey explicitly relies upon this point in holding that wrongdoer control as an 'absolute condition' has been abolished. However, this inference struggles in the face of the place found for wrongdoer control in 'prima facie case for giving permission' as well as this section's consistency with the former regime.

Under the common law rules would it have made sense to say that an action that ostensibly could have been brought pursuant to the fraud on the minority exception - because of both the nature of the wrong and wrongdoer control over the general meeting - could not in fact be brought because the wrong had already been ratified? Some commentators would say it would not because the fraud on the minority exception only applied to non-ratifiable wrongs, which are by definition non-ratifiable. However, as argued in Part II of this article, there is no such category of wrongs which are of themselves non-ratifiable. All wrongs that fell within the fraud on the minority exception were ratifiable, just not with the assistance of the votes of the wrongdoer. That is, under the common law rules, ratification or authorisation by a disinterested general meeting vote would have operated as a bar to a derivative action that complied with the other criteria of the fraud of the minority exception, including wrongdoer control. Such ratification or authorization - which necessarily must be facilitated by the wrongdoer's abstention - would have cured the wrong, resulting in there being no cause of action in relation to which litigation could be brought. One could readily imagine circumstances where this could arise. For example, a new minority shareholder brings an action against the longstanding and wrongdoing controllers only to discover that the former disinterested shareholders have ratified the decision; or following commencement of the litigation the remaining disinterested shareholders vote in favour of ratification. Accordingly, sections 262(2)(b) and (c) may be viewed as a restatement of the prior common law position on effective ratification and authorisation even in the presence of wrongdoer control. If the same rule was applicable under the pre-Act position its presence in the Act cannot be relied upon to draw an implication of the abolition or the wrongdoer control requirement.

The relationship between the corporate interest rule in sections 263(2)(a) and 263(3)(b) can also be read as a consistent restatement of the common law regime as set forth in Mumbray $v$ Lapper ${ }^{55}$ and Airey $v$ Cordell, 86 where corporate interest

85 [2005] EWHC 1152.

86 [2006] EWHC 2728. 
becomes a consideration following the establishment of wrongdoer control. Warren $\mathrm{J}$ observed in Airey $v$ Cordell that the court should only exercise its discretion to prevent the bringing of a derivative action where it is clear that the board would not grant permission to continue: 'where no board acting reasonably could decide to take proceedings'. Section 263(2) could be read as a procedural restatement of this position. It is noteworthy in this regard that courts have adopted Airey $v$ Cordell's approach to the interpretation of section 263(2)(a). ${ }^{87}$ However, in Airey v Cordell Warren J held that once the action could be held as being in the corporate interest the court should not prevent the action from proceeding. The Act does not adopt this approach and, in section 263(3)(b), allows the court who has concluded that a hypothetical director would not 'not seek to continue the claim', to continue to have regard to the importance that the hypothetical director would attribute to continuing with the litigation. However, this arguably amounts merely to a legislative adjustment of the developing common law objective corporate interest test and does not imply anything about a prior rule preventing the bringing of a derivative claim where there is no wrongdoer control.

What then of the other discretionary factors in section 263(3) and (4)? The requirement that the court consider the bona fides of the derivative litigant is a restatement of the similar common law rule. Accordingly, this rule has nothing to stay about the role of wrongdoer control as an 'ex-ante' pre-requisite to court consideration of this factor. Nor do the rules requiring consideration of likely ratification, authorisation and the views of the disinterested shareholders. ${ }^{88}$ These rules provide in effect the same function - they codify the position set forth in Smith $v$ Croft (No. 2) and encourage the courts to take account of disinterested shareholder views on whether the litigation is in the company's interest.

However, sections 263(3)(e) and (f) of the Act create some difficulty for the reading of the Act that suggests that the 'prima facie case' inquiry in Stage 1 involves a determination of whether there is wrongdoer control or another form of corporate incapability. Subsection (e) requires regard to whether the company has decided not to commence litigation and subsection ( $f$ ) requires regard to whether the unlawful act also gives rise to a personal claim of the member as well as the derivative claim. If it is correct that the proper plaintiff rule remains applicable then obviously the determination of whether there is wrongdoer control or some other form of general meeting disability are necessarily prior to the corporate interest considerations set forth in 263(3). However, the consideration of the company's decision about the litigation and the availability of an alternative remedy could be interpreted to require consideration of factors that are directly concerned with the capability of the company to make a decision about the litigation independently of the wrongdoer's interests. That is, these considerations may be interpreted to raise factors that would be addressed by a wrongdoer control inquiry. They would not, therefore, make sense as part of an assessment of

${ }^{87}$ See, for example, Iesini v Westrip Holdings Ltd [2011] 1 BCLC 498.

88 Section 263(3)(c)(d) and (4) Companies Act 2006. 
whether litigation should continue following a finding of wrongdoer control and, accordingly, if such readings are correct, imply abolition.

Let us take first the consideration of the company's decision in section 263(e). The first question we need to answer is which organs are intended by reference to 'the company'. Clearly the board's decision is the company's decision. But is a general meeting's decision on the litigation also the company's decision? At common law the answer is a relatively clear 'yes'. Although some courts, most notably Breckland Group Holdings Ltd v London \& Suffolk Properties Ltd ${ }^{89}$ have held otherwise and focused only on the distribution of power in the articles (which typically would not empower the general meeting to make the decision), most courts and commentators are of the view that there is such a reserve power for the general meeting. The most important support for this view is, of course, the proper plaintiff rule which presumes the reserve power of the general meeting to make a litigation decision..$^{90}$ If the proper plaintiff rule has been abolished then without this support it seems probable that the literal constitutional approach adopted in Breckland Group Holdings Ltd is correct, which will mean that in nearly all companies $^{91}$ the general meeting will not have the power to make a litigation decision for the company and 'company' in section 263(3)(e) means only the board. ${ }^{92}$ On the other hand, if the proper plaintiff rule has survived then 'company decision' in section 263(3)(e) may be interpreted as either the board's or the general meeting's decision. Yet paradoxically, as we shall see below, if 'the company's' decision means also the general meeting's decision then this generates perhaps the strongest implication of abolition.

Courts interpreting this provision to date have viewed it as a means of considering the views of the board or a special committee authorised to act on behalf of the board..$^{93}$ If courts were to interpret 'company' to mean only the board, ${ }^{44}$ then this provision is clearly consistent with the retention of the proper plaintiff rule and wrongdoer control. This consideration may be understood as the

89 [1988] 4 BCC 452.

90 (1843) 2 Hare 461, 492-493.

91 We ignore here those exceptionally rare companies whose articles explicitly provide for retention of managerial powers by the shareholders or retention of specific power in relation to the litigation decision.

92 This is distinct from the power to instruct the board to take action (by special resolution according to Article 4, Model Articles for Public and Private Companies), which would not amount to the litigation decision by the company, but only a decision to instruct the board to take the litigation. This model article provision does not provide for a retention of managerial corporate power with the shareholder body (although clearly the articles could do so). Formally then, such an instruction is not a decision of the company to pursue or not to pursue the litigation. To see this more clearly, if the shareholder body resolves to instruct the board to commence litigation, if the board simply did not act on this instruction the shareholders, unless they changed the articles, would not be empowered to commence litigation (assuming no reserve power) on behalf of the company as the corporate contract does not provide them with that power. Their remedies would be for failure of the directors to comply with the terms of the constitution (section 171 Companies Act 2006) or to remove the directors.

${ }^{93}$ Kleanthous v Paphitis [2011] EWHC 2287.

94 It is noteworthy that, the Explanatory Notes to the Bill at [473] (available at http//: http://www.publications.parliament.uk/pa/ld200506/ldbills/034/en/06034x-h.htm\#11) refer to three ways which litigation may be commenced to the Act including: (i) a board decision to commence litigation, (ii) action commenced by a liquidator and (iii) a derivative action. It does not refer to a litigation decision made by the general meeting. 
Act's attempt to incorporate consideration of the board's views - even in the context of wrongdoer control of the general meeting - weighted according to their independence of the directors from the wrongdoers..$^{95}$ Such a consideration would amount to a restatement of the court's position in Prudential Assurance $v$ Newman which viewed the independent board's decision as a relevant consideration in deciding whether to permit the derivative action. ${ }^{96}$

Ignoring the conundrum identified above, let us consider the interpretative consequences if 'company decision' is interpreted to mean the decision of the shareholders in general meeting as well as the board's decision. What sense then would it make to consider the decision of the company in general meeting after wrongdoer control has been established? If the wrongdoers voted in the decision then this would, nonsensically, be akin to taking account of the wrongdoer's view; if the wrongdoers abstained and the meeting voted against the litigation then there would be no wrongdoer control and Stage 2 would never have been reached. ${ }^{97}$ Accordingly, in providing for consideration of the general meeting's decision not to pursue the claim section 263(3)(e) implies abolition.

However, whether or not wrongdoer control has been retained or replaced by the Act it is clear that requiring consideration of the company's decision (whether the general meeting or the board) is designed not merely to consider the decision itself but the make-up and views of the corporate organ when making the decision. A board decision effected by the wrongdoers would not be relevant. Similarly, if a wrongdoer control threshold requirement is not retained by the Act, yet the decision of the general meeting was passed by reason of the votes of the wrongdoers then the decision itself would not be a relevant consideration for the court, but the makeup of the vote - votes cast, the number of disinterested shareholders for or against - would be relevant. For example, if a vote was taken where the controlling wrongdoers voted but the results revealed that a majority of the disinterested shareholders voted with the wrongdoers, the decision is relevant for the court not because of the actual decision but because it provides information about the disinterested shareholders' position. When the provision is viewed in this way the consideration makes sense even with a wrongdoer control threshold requirement. It represents another way provided by the Act for taking into account the views of the disinterested minority.

In summary, section 263(3)(e) generates an implication of abolition if company decision means the general meeting's decision as well as the board's decision. It does not generate an implication of abolition if it means only the board's decision. This implication is softened, however, by the availability of a reading of this consideration which is consistent with the retention of wrongdoer control. Nevertheless, this reading departs somewhat from the literal reading of

\footnotetext{
95 The Company Law Review, Developing the Framework (paras 4.129-4.139) recommended a disinterested director bar to bringing an action. 96 [1982] Ch 204, 221.

${ }^{97}$ See text to note 15 .
} 
the provision which focuses on the decision not the voting make-up of the decision. A more fundamental challenge to an implication of abolition arising from this provision is that without the proper plaintiff rule a discussion of any implication generated by requiring consideration of the general meeting's litigation decision is nonsensical because the general meeting would not have the power to make that decision. That is, paradoxically, the implication of abolition is premised on its retention. A court burdened with having to unpackage the meaning of this section 263(3)(e) would, therefore, struggle to find a clear and compelling implication that the proper plaintiff rule and its corollary of wrongdoer control have been abolished.

Subsection ( $f$ ) also provides support for the view that the wrongdoer control requirement had been abolished. This provision is a modified version of the 'alternative remedy' bar to the bringing of a derivative action under the rule in Foss $v$ Harbottle. Subsection (f) requires the Courts to consider the existence of an alternative action that could be brought in the members own name. As noted above, in Konamaneni v Rolls-Royce Industrial Power (India) Ltd ${ }^{88}$ Lawrence Collins J observed that the alternative remedy consideration was 'not an independent bar to a derivative action, but simply an example of a case where there will be no relevant wrongdoer control'. That is, the alternative remedy is relevant because it removes the actual wrongdoer control problem. In Barrett $v$ Duckett, ${ }^{99}$ the case generally cited for the alternative remedy consideration, one of the alternative remedies which was of particular importance to the court was the option of putting the company into liquidation, which would have rendered the company subject to liquidator and not wrongdoer control. Through this lens, the alternative remedy consideration is only relevant to the determination of whether or not there was wrongdoer control. If this is correct, and wrongdoer control continues to apply as a pre-section 263 threshold condition, then the presence of subsection ( $f$ ) is nonsensical; which by implication suggests that the proper plaintiff rule and its corollary, the wrongdoer control requirement, have been abolished.

Of course, this is a reading that rests heavily on Konamaneni's understanding of the conceptual basis of the alternative remedy consideration. Although in Barratt $v$ Duckett it is true that the court focused on the effect of the alternative remedy on wrongdoer control, it is also the case that in Barrett $v$ Duckett the court appeared to view the availability of the unfair prejudice remedy, as an alternative remedy, as a relevant consideration which had no connection to the wrongdoer control determination. Subsequent cases gravitated away from Lawrence Collins J's 'restricted meaning'100 Furthermore, the Act does not use the language of 'alternative remedy' used by the courts and adopted by the Law Commission's derivative action proposal, ${ }^{101}$ but rather refers only to the availability of a personal

\footnotetext{
98 [2002] 1 BCLC 336.

99 [1995] 1 BCLC 243 (CA), per Peter Gibson LJ.

100 Airey v Cordell [2006] EWHC 2728 noting that 'Lawrence Collins J was giving a very restricted meaning to the there being no alternative remedy'.

${ }^{101}$ Law Commission, Shareholder Remedies (Final Report), [50.7(f)].
} 
claim. This suggests that if there are two understandings of alternative remedy from the case law, section 263(f) has adopted the understanding that is unconnected to wrongdoer control. Through this lens, subsection (f) is consistent with an pre-Section 263 wrongdoer control determination.

Based on an interpretation of the provisions in Part 11, although we find some limited support for an implication of abolition in section 263(3)(e) can one say consistently with Lord Browne-Wilkinson in $\mathrm{R} v$ Secretary of State for the Home Department, Ex Parte Pierson, that Parliament 'has clearly indicated' an intention to change this fundamental common law rule? If we extricate from our minds all extra-legislative material discussed below about the mischief at which the Act was aimed or Parliament's intention as evidenced by Parliamentary debates, can we confidently say that the language of the statute provides a 'compellingly clear' implication of abolition? The Act clearly allows for two possibilities. A literal reading of the Act divorced from any understanding of the pre-Act approach would provide that permission is a function only of the considerations allowed by section 263. However, if one juxtaposes the pre-Act common law rules and civil procedure rules next to Part 11 a strong inference is available that - apart from the abolition of wrong-based restrictions on the bringing of derivative actions - the Act merely provides a procedure for applying the proper plaintiff rule and codifies in statute the common law's approach to determining whether, following the threshold determination of general meeting capability, allowing the derivative action to proceed is in the company's interests. If rules of statutory interpretation create a presumption in favour of continuity which must be rebutted explicitly or by compelling clear legislative implication, the case for the continuing application of the proper plaintiff rule, as a substantive rule of law, may have it.

\section{IN SEARCH OF MISCHIEF AND LEGISLATIVE INTENTION}

Principles of statutory interpretation allow the judge to have regard to two sources of extra-statutory materials: first, evidence of the mischief which the legislation aimed to remedy, ${ }^{102}$ and, secondly, where the meaning of legislation is ambiguous or obscure then, pursuant to the House of Lords' decision in Pepper v Hart, ${ }^{103}$ recourse may be had to ministerial statements made in Parliament during the legislative debates.

\footnotetext{
102 On the ability of the courts to take into account Law Commission reports for understanding the mischief at which the legislation is aimed see Factortame Ltd v Secretary of State for Transport [1990] 2 AC 85, 122 (HL). 103 [1993] AC 593.
} 


\section{A. The Mischief of Part 11}

In 1592 the Barons of the Exchequer observed that 'the office of all judges is always to make such construction as shall suppress the mischief. ${ }^{104}$ But to suppress the mischief one has to be able to identify the mischief as it was understood when the Bill was laid before Parliament. In Black-Clawson International Ltd v Papierwerke Waldhof-Aschaffenburg $A G^{105}$ Lord Reid observed in regard to the identification of 'mischief' that:

In addition to reading the Act, you look at the facts presumed to be known to Parliament which the Bill which became the Act in question was before it, and you consider whether there is disclosed some unsatisfactory state of affairs which Parliament can properly be supposed to have remedied by the Act.

In Black-Clawson a report published months before the Foreign Judgments (Reciprocal Enforcement) Act 1933 was enacted was deemed to have identified the mischief of this statute. The interpretative problem is how to identify whether evidence of mischief has indeed been adopted by the executive in drafting the Bill and placing it before Parliament. The existence of a pre-Bill report is uninformative about mischief unless it can be shown unequivocally that the report's view of the mischief was subsequently adopted. ${ }^{106}$ For the purposes of Part 11 there are two primary sources for the identification of mischief: the Explanatory Notes to the Company Law Reform Bill and the Law Commission's report on Sharebolder Remedies.

The chronological starting point for identifying the mischief addressed by Part 11 is the Law Commission's 1997 report on Shareholder Remedies. The Lord Chancellor's reference to the Law Commission is unrevealing, requesting merely that the Commission 'carry out a review of shareholder remedies with particular reference to $[\ldots]$ the rule in Foss $v$ Harbottle and its exceptions'.107 The Commission's Consultation paper outlines the main concern to be 'the complexity and obscurity' of the common law derivative action rules. ${ }^{108}$ The paper also notes that following the Cadbury, Greenbury and Hampel Committees 'there has been much interest in improving the accountability of directors in listed companies',

${ }^{104}$ Heydon's Case 3 Rep. 7b.

105 [1975] 1 All ER 810, 814. See also: Eastman Photographic Materials Co. v Comptroller-General of Patents Designs and Trademarks [1898] AC 571.

${ }^{106}$ See Assam Railways and Trading Company, Limited v Commissioners of Inland Revenue [1935] AC 445. per Lord Wright, noting that 'the Report of the Commissioners is even more removed from value as evidence of intention, because it does not follow that their recommendations were accepted' at 458. In Black-Clawson International Ltd v Papierwerke Waldhof-Aschaffenburg AG [1975] 1 All ER 810 at 823 per Viscount Dilhorne: 'if the report of the committee merely contains recommendations, while I think regard may be had to them, little weight maybe attached to them, as it does not follow that Parliament has accepted them. Parliament may have decided to go further or not as far'.

${ }^{107}$ Law Commission, Shareholder Remedies - Consultation (hereinafter 'Consultation Report') [1.2] (available at: http//: http://lawcommission.justice.gov.uk/docs/cp142 Shareholder Remedies_Consultation.pdf). 108 Ibid, [1.4]. 
however, the report observes further that 'since the content of director's duties is outside this project, issues as to the accountability of directors or other companies are also outside the project'. ${ }^{109}$ Accordingly, for neither the Government of the day nor for the Commission was the effect of the wrongdoer control requirement, particularly in relation to listed companies, an initial focal point of concern or mischief. The mischief of note was the need to address the complexity and obscurity of the existing provisions.

The recommendations of the Final Report, however, extend beyond simplification and transparency. Inspection of the Final report reveals a commitment to abrogate the fraud on the minority exception and to replace it with a court controlled process in which the courts are empowered to consider all the circumstances. Wrongdoer control was viewed as part of this exception, and therefore, for the Law Commission, as part of that abrogation. In the Commission's consultation paper, detailed attention was given the practical problems associated with determining whether the wrongdoers were in control. ${ }^{110}$ The Law Commission recommended that the new procedure 'replace entirely the common law right to bring a derivative action'.111 Although the Commission reaffirmed the proper plaintiff rule as a 'guiding principle of the law on shareholder remedies'112 necessarily the abrogation of the wrongdoer control requirement involves the abrogation of the proper plaintiff rule as a substantive rule of English law. As we noted above, the wrongdoer control requirement is umbilically connected to the proper plaintiff rule which enables derivative actions only where the general meeting is incapable of acting because of, for example, wrongdoer control. Where the general meeting is capable of functioning, the proper plaintiff rule prevents derivative litigation. Pursuant to the Law Commission's recommendation the proper plaintiff rule would become a presumption or a preference which would be rebuttable even in the absence of wrongdoer control - ie., where the conditions for leave were satisfied. ${ }^{113}$ The Rule in Foss $v$ Harbottle was not therefore retained by the Law Commission's recommendations.

The Explanatory Notes to the Companies Act 2006 observe that Part 11 was not intended to be 'a substantive rule to replace the rule in Foss $v$ Harbottle'. The Notes to the Act further observe that 'it will not be necessary for the applicant to show that the wrongdoing directors control the majority of the company's shares'.114 However, these Notes are of no relevance to understanding what was intended by Parliament or the mischief addressed by the Act. They amount only to post-

\footnotetext{
${ }^{109}$ Consultation Report, [1.5].

${ }^{110} \mathrm{Ibid}$ [4.13].

${ }^{111}$ Final Report, [6.52].

112 Law Commission Consultation Paper, [14.11, 14.12] (reaffirmed in the Final Report, [1.9]).

113 The Law Commission's Final Report, at [6.93]: 'As we made clear in the consultation paper, in the absence of circumstances justifying the grant of leave, we consider that the proper plaintiff principle should apply since, in the words of the Court of Appeal in Prudential it "[...] is fundamental to any rational system of jurisprudence"" (emphasis added).

114 Explanatory Notes to the Companies Act 2006, [491].
} 
enactment guidance provided by the Department of Business. As the Inner House in Imperial Tobacco Ltd $v$ Lord Advocate ${ }^{115}$ recently observed with regard to an attempt to rely on the Explanatory Notes to the Scotland Act, such notes are prepared after the enactment and, therefore, the 'value of these notes for the purpose of interpretation of the statute is very limited'. This is wholly correct as a matter of principle. To allow such notes to count as evidence of Parliamentary intent would be to transfer power to the Executive to form Parliamentary intent after enactment. These notes should, as Lord Hamilton, the Lord President, observed 'be regarded merely as a commentary on the provisions'. The weight of any commentary stands on the persuasiveness of its arguments. As Explanatory Notes to the Act typically provide only statements of position rather than arguments for positions they are unlikely to carry much weight. We cannot artificially enhance the weight of this commentary by appealing to the fact that such notes are prepared by people very close to the legislative process. We do not know: who prepared or supervised the preparation of these notes; their level of seniority; the time they have spent in the Department or on the Bill; or their understanding of the area of law addressed by the statute.

By way of contrast, the Explanatory Notes to the Company Law Reform Bill are relevant to understanding the context and mischief of Part 11.116 In this regard, Lord Steyn has extra-judicially observed that: 'Explanatory Notes will sometimes be more informative and valuable than reports of the Law Commission or advisory committees, Government green or white papers, and the like'.117 This view is particular apposite in the case of Part 11 where there was a considerable time delay between the Law Commission's proposal and the Bill, and where the Government appeared to be uncertain during this period as to what to do with the proposal, as evidenced by a 2002 White Paper on Modernising Company Law which, as Arad Reisberg observes, 'was somewhat equivocal on these reforms'.118

The Explanatory Notes to the Bill do not suggest that the mischief addressed by the Act was wrongdoer control or that the Act was designed to abolish the proper plaintiff rule. Having set forth the Note's understanding of the common law,

115 [2012] CSIH 9 (Inner House) at [13].

116 See Imperial Tobacco Ltd v The Lord Advocate [2012] CSIH 9 (Inner House) at [13] where the Lord President observed when rejecting the value of Explanatory Notes to the Act: "They accordingly do not have the interpretative value which explanatory notes which accompany a Bill in its passage through Parliament can have because the latter can provide an objective setting or contextual scene for the statute or contain a clear assurance by the executive in Parliament about the meaning of the provision', citing Westminister City Council $v$ National Asylum Support Service [2002] UKHL 38 at [5]. See Steyn LJ, 'Pepper v Hart: A Reexamination' (2001) 21 OLJS 59. Lord Steyn himself suggests that the wording of the notes on a particular clause may be admissible against the government where the government attempts to rely on a reading of a statute different from what they claimed in Parliament the clause meant. With regard to context and mischief he observes : 'Insofar as the Explanatory Notes cast light on the objective setting or contextual scene of the statute, and the mischief at which it is aimed, such materials are therefore always admissible aids to construction. They may be admitted for what logical value they have'.

117 Ibid 71, also observing that 'I would expect such documents to be of great assistance to the courts in mastering the scheme and structure of sometimes impenetrable legislation'.

118 See Reisberg above n.49 at [note 30]. Department for Trade and Industry, Modernising Company Law (White Paper) (Cm 5553-I). 
including the 'fraud' and wrongdoer control prerequisites, ${ }^{119}$ the Notes observe both that: "the clauses do not formulate a substantive rule to replace the rule in Foss $v$ Harbottle, but rather a new procedure for bringing such an action which set down criteria for the court distilled from the Foss $v$ Harbottle jurisprudence;; 120 and that 'this Part [does] not seek to overturn the [common law's] well-established principles'.121 In contrast to the Act's Explanatory Notes, there is no mention of the fact that it is no longer necessary to demonstrate wrongdoer control. On the contrary, the Explanatory Notes to the Bill set out wrongdoer control as an existing part of the common law and then proceed to observe that the Bill does not seek to overturn the law's existing principles. For the Notes to the Bill the permission procedure is the means by which a shareholder can pursue an action where 'the company is improperly prevented from bringing proceedings'. ${ }^{122}$ The Notes to the Bill refer to the objective of implementing the Law Commission's recommendation that there should be 'a new derivative procedure with more modern, accessible and flexible criteria'. But they do not simply say that Part 11 implements the Law Commission's specific reform recommendations.

Although not admissible evidence of mischief, it is a noteworthy aside that there is other evidence to suggest that the view that the Rule in Foss v Harbottle, understood as the proper plaintiff rule, was not being amended by the Bill was held within the Executive. In a letter to the Financial Times in 2005, Minister Alun Micheal provided clarification that although, contrary to prior law, the Bill provided for derivative suit in respect of cases of negligence it 'will not result in a major change in the law'.123

Accordingly, as to the mischief addressed by the Bill there is a direct conflict between the Explanatory Notes to the Bill which do not view wrongdoer control or the replacement of the common law rules as the mischief addressed by the Act and the Law Commission's recommendations which, if taken as the mischief addressed by the statute, do. In support of this understanding of the Notes to the Bill's position on continuity there are some important differences between the Bill and the Commission's proposals. ${ }^{124}$ Perhaps the most noteworthy difference between the Commission's proposal and the Act is not one which is relevant to this analysis - namely the Stage 1 requirement to establish a 'prima facie case for giving permission' - as this was introduced in a subsequent amendment to the Bill. ${ }^{125}$ Other differences between the Bill and the Commission's proposal are relevant. Note in particular that the Commission recommended that the court

${ }^{119}$ Explanatory Notes to the Company Law Reform Bill, [474-475] and again in [481].

${ }^{120}$ Explanatory Notes to the Company Law Reform Bill, [480].

${ }^{121}$ Explanatory Notes to the Company Law Reform Bill, [482].

122 Explanatory Notes to the Company Law Reform Bill, [481].

123 'Effect in statute for a longstanding shareholder right' A. Michael, 9 November 2005 Financial Times (letter).

124 See $R v$ Allen [1985] AC 1029, 1035 as an example of the comparison of a report's recommended changed and the subsequent Act as a relevant factor for determining whether a report provides evidence of mischief (which in this case was 'identical'). See also Black-Clawson, above at n. 101 at 823.

${ }^{125}$ See above at. n. 75. 
considers whether there is an 'alternative remedy'. As noted above the alternative remedy consideration had two aspects at common law. The first was that the availability of the alternative remedy meant that there was no wrongdoer control, for example, because a liquidator could be appointed. The second was that an alternative personal remedy existed for the derivative litigant. As also noted above, had the former understanding been retained by the Act then that would support the view that the Act has abolished a wrongdoer control requirement. However, the Bill and the Act elected not to take the Commission's position and focused only on the second aspect of the alternative remedy consideration, a position which we established in Part IV is consistent with the view that the wrongdoer control requirement has not been abolished.

It is also noteworthy that the Commission's draft proposals contained a demand requirement that provided that prior to being able to commence derivative litigation notice must be served on the company setting forth the particulars of the claim and informing the company that if it did not bring the claim then derivative litigation would be commenced. ${ }^{126}$ The Commission's proposals would have given the company a 28 day grace period to make the litigation decision, during which the derivative claim could not be brought. This demand mechanism may be viewed as a different way of giving effect to the idea that the proper plaintiff rule is 'the guiding principle of the law'. The demand proposal would have allowed, and provided time for, the company itself to make a decision about the enforcement of its rights. It is an acknowledgement that in the first instance it is a decision for the company. But this demand mechanism did not make it into the Bill or the Act. Without it, if the common law rules have been replaced by the Act, then the Act pays less regard to the proper plaintiff principle and represents a more substantial departure from the common law - than the Commission's proposals. That is, less continuity whilst the Notes to the Bill professed more continuity. Unless, that is, taking the Notes at their word, it is not necessary to provide a different balance between the proper plaintiff principle and director accountability, because the Rule in Foss $v$ Harbottle remains in place.

Given the inconsistency between the Notes to the Bill and Commission's position and proposals, and the Notes chronological proximity to the Bill, one cannot take - as Roth J did in Bamford $v$ Harvey and the Inner House did in Wishart $v$ Castlecroft Securities - the Commission's recommendations or proposals as evidence that the mischief at which the Act was aimed was to replace the common law rules and to abolish the corporate incapability / wrongdoer control requirement. The mischief which we can take from both of these sources is the need for a new, modern, flexible and assessable mechanism. But, following the Explanatory Notes to the Bill, not one that - apart from the category of wrongs that can be subject to derivative claims - alters the prior substantive legal position.

126 Law Commission Final Report [6.58-6.60]. The Commission observed that 'the vast majority of respondents agreed with the provisional recommendations. Several respondents suggested that 28 days was too short' [6.59]. 


\section{B. Wrongdoer Control ANd Ministerial StATEMENTS}

\section{The scope of Pepper $v$ Hart}

Pursuant to the Rule in Pepper v Hart ministerial statements made in Parliament, may be relied on as an interpretative aid where the statutory language is ambiguous or obscure. Where admissible, ministerial statements do not determine the meaning of the provision in question but form part of the 'legislative background' to be taken into account when interpreting the provision. ${ }^{127}$

The nature of the legislative process means that statements of ministers in Parliament as probative evidence of Parliamentary intention must be treated with great care. The relationship between intention and a draft bill may not necessarily take the form of Intention-Bill-Act. It may often be the case that what amounts to the 'intention' of a Bill in relation to a specific point of law may not have been given careful consideration by any minister or any of her aids prior to the drafting of the Bill. ${ }^{128}$ The 'intention' of a Bill as stated in Parliament may, therefore, only manifest itself in response to a Parliamentary question once the Bill has been laid before Parliament. 'Intention' formed in the 'heat of the question' may, understandably, place pressure on the minister's command of his brief, ${ }^{129}$ which in turn may generate statements which, although equally valid as 'ministerial statements', generate uncertainty and contradiction rather than clarity. Furthermore, where provisions allow for different interpretations, 'intention' may be in dispute and the subject of power struggles within Government; it may also change as executive and administrative personnel changes. Necessarily, such after the fact or shifting 'intention' creates the scope for prior ministerial statements or statements in the Explanatory Notes to the Bill to contradict later statements.

An important question in determining the relevance of ministerial statements of intention made in Parliament is how clear and certain do they have to be in order to be admissible. Is there any scope to rely on statements where there are other statements which contradict, or are inconsistent with, the statement that is relied upon? In $R v$ Secretary of State for the Environment, Transport and Regions, Ex Parte Spath Holme their Lordships observed that in order to rely on the exception in Pepper $v$ Hart the legislative record must be 'clear and unequivocal' and amount to a 'consistent series of answers given by ministers' amounting to view that 'would almost certainly settle the matter immediately one way or the other'. ${ }^{130}$ Lord Nichols in this case observed 'that the Parliamentary statement relied upon must be clear and unequivocal. Otherwise it is of no real use. Parliamentary statements

${ }_{127} \mathrm{R} v$ Secretary of State for Environment, Transport and the Regions, Ex parte Spath Holme Ltd [2001] 2 AC 349 per Lord Nicholls of Birkenhead at 399.

128 See Lord Hoffmann, 'The Intolerable Wrestle with Words and Meanings' (1997) 114 South African Law Journal 669.

129 Ibid.

${ }_{130} \mathrm{R} v$ Secretary of State for the Environment, Transport and the Regions [2001] 2 AC 34 per Lord Bingham of Cornhill quoting Lord Reid in R $v$ Warner [1969] 2 AC 256 and observing also that 'the conditions laid down by the house in Pepper $v$ Hart be strictly insisted upon'. 
rarely satisfy this test on the points of interpretation which come before the courts'. ${ }^{131}$ The Rule in Pepper $v$ Hart does not allow courts to attempt to resolve any uncertainty as to what was meant or intended by the Executive.132 As Lord Bingham observed in Ex parte Spath Holme:

Unless Parliamentary statements are indeed clear and unequivocal [...] the court is likely to be drawn into comparing one statement with another, appraising the meaning and effect of what was said and considering what was left unsaid and why. In the course of such an exercise the court would come uncomfortably close to questioning the proceedings in Parliament contrary to article 9 of the Bill of Rights 1688 (1 Will \& Mary, sess 2, c 2) and might even violate that important constitutional prohibition. ${ }^{133}$

Accordingly, in their Lordships view the presence of contradictory or inconsistent statements would exclude reliance on any statement. If ministerial statements are admissible as probative evidence of intention it is because Parliament, acting through its members, is deemed to have adopted or to share this view as to what the provision is intended to achieve. But this presumptive relationship between ministerial statement and Parliamentary intent disintegrates if ministerial statements are unclear or equivocal. Parliament can only have one intention and where the Executive itself is unclear or inconsistent then logically these statements can have no probative value for such singular Parliamentary intention. The only way to connect equivocal statements to Parliamentary intent would be to treat Parliamentary intention as majority member intention and then to determine which members adopted which ministerial statement of intent. But not only is such a determination impossible, such an approach is inconsistent with the Rule in Pepper v Hart and, as Lord Bingham observed, may well be unconstitutional because it amounts to questioning the debates or proceedings of Parliament. As a result, where the Executive's statements are equivocal all statements fall and are inadmissible. It does not matter whether: one of the statements was made more often than the other; one statement makes less sense that the other; one of the statements was specific and the other one general; or one of the statements was made by a minister thought to be more in command of his brief than another.

${ }^{131} \mathrm{R} v$ Secretary of State for Environment, Transport and the Regions, Ex parte Spath Holme Ltd [2001] 2 AC 349 at 398. See also: Wilson v First Country Trust Ltd [2003] UKHL 40; Harding v Wealands [2006] UKHL 32; Yarl's Wood Immigration Ltd v Bedfordshire Police Authority [2008] EWHC 2207 (Comm).

132 See R. Unison [2009] EWHC 3221 per Cranston J: 'the rival contentions in this case about the Hansard material underlines the danger of resorting to it except when absolutely required under Pepper $v$ Hart...There are also the difficulties of interpreting what the minister or promoting parliamentarian means which can result, as in this case, in the focus moving from understanding the language of the legislation as enacted to attaching a meaning to the language of debate'. However, see R.v JTB [2009] AC 1310 at [21] where their Lordships rely on Pepper $v$ Hart yet dismiss a contradictory statement made by a Government minister. A position, which is inconsistent with the position in Pepper v Hart and Spath Holme but also with the theory underpinning Pepper $v$ Hart discussed in the following paragraph.

${ }_{133} \mathrm{R} v$ Secretary of State for Environment, Transport and the Regions, Ex parte Spath Holme Ltd [2001] 2 AC 349 at 39. Article 9 of the Bill of Rights 1688 provides that ' debates or proceedings in Parliament ought not to be impeached or questioned in any court or place out of Parliament'. 


\section{Pepper $v$ Harting Part 11}

Assuming that Part 11 of the Act can be rationally constructed consistently with the different interpretations of the Act set forth above, there is a clear ambiguity supporting the consideration of Parliamentary material. ${ }^{134}$ Most commentators are of the view that this material supports the position that the purpose of Part 11 was to abolish wrongdoer control in order to make derivative litigation available against widely held companies. ${ }^{135}$ However, as we shall see below, the overall record is not unequivocal raising real doubt about its admissibility as an interpretative aid.

The Law Commission's affirmation of the proper plaintiff rule as a guiding principle, but its actual rejection of the proper plaintiff rule as a substantive rule of UK company law appears to generate ministerial confusion and a resulting problem for legislative intent. For Lord Goldsmith, the Attorney General, although the Bill's objective was to implement the Commission's recommendations it did not, consistently with the view expressed in the Explanatory Notes to the Bill, 'introduce any major change of principle to the law in this area'. ${ }^{136}$ As noted above, the removal of the wrongdoer control bar to bringing an action is clearly a significant change of principle; one that would challenge the proper plaintiff principle. More precise Parliamentary language on wrongdoer control was provided by Lord Goldsmith on several occasions. $\mathrm{He}$ observed that under the common law regime there were significant difficulties in identifying whether there was wrongdoer control and clarified that having to demonstrate wrongdoer control does not appear in the Government's approach'.137 In a later debate, he observed that 'we made a conscious decision not to continue [with wrongdoer control] as part of the derivative claim procedure'. 138

How do we make sense of this 'no change but change' mantra? The proper plaintiff rule is (was) an elemental rule of UK company law. Wrongdoer control is the corollary of that rule. To dismantle it abolishes the foundational rule and amounts to a 'major change of principle'. Perhaps the Government incorrectly viewed wrongdoer control as simply part of the fraud on the minority exception, which was being abolished, and not part of the proper plaintiff rule, which remained in place. This reading is affirmed by the Solicitor General in the debate in the following July when he observed, on the morning of 13 July 2006, that although the Government was reaffirming 'the purpose behind the Rule in Foss $v$ Harbottle and that we do not seek in any way to repeal it' (emphasis supplied):139

\footnotetext{
134 The courts reticence to use Pepper $v$ Hart often manifests itself in a finding that legislation is sufficiently clear. Such a reading clearly cannot be ruled out in relation to Part 11.

135 See above note 48.

136 Grand Committee, House of Lords, 27 February 2006 Hansard Column CG4.

137 Ibid CG 7.

${ }^{138}$ Hansard (HL) (9 May, 2006, Column, 888).

139 Standing Committee D, Company Law Reform Bill 13 July 2006. Column No. 661.
} 
The new statutory procedure differs from the common law in two key respects. First, we do not want the claimant to have to show 'wrongdoer control'- that the directors whom the claimant believes have acted in breach of their duties to the company are in control of the company-as this may make it impossible for a derivative claim to be brought successfully by a member of a widely held company. ${ }^{140}$

This 'no change but change' contradiction generated confusion in the debates themselves. In the afternoon session on the same day, following the tabling of an amendment to reintroduce a wrongdoer control requirement and in response to Jonathan Djanogly MP's question: 'am I right in thinking that the law remains as it is in terms of fraud on minority and that it will just not be put in the Bill?', the Solicitor General unhelpfully replied: 'Let me examine that. Our aim will be to ensure that we get the provision correct, and it is important that this area is clarified. It will not remain as it is, in the sense that, at the moment, we and the Law Commission are saying that there is a certain lack of clarity'. ${ }^{141}$ He agreed to send a note on the issue to the Commons' Committee; a note that this author has been unable to find on the public record. This Minister's position on wrongdoer control was repeated in a subsequent debate. ${ }^{142}$

The Parliamentary record reveals a reform body / legislative intent bias in favour of viewing Part 11 as abolishing the wrongdoer control pre-requisite to make it possible to bring derivative litigation against widely-held companies. But is this a Parliamentary record that would be admissible to support a contention that Part 11 has abolished a requirement of wrongdoer control to the bringing of a derivative claim? It is submitted that it would not. As noted above, pursuant to the Rule in Pepper $v$ Hart what the Executive intended, as stated in Parliament, may be relied on as an interpretative aid where that record of intention is so 'clear and unequivocal' that it would 'almost certainly settle the matter immediately one way or the other'. ${ }^{143}$ The Parliamentary statements and material on Part 11 do not satisfy this threshold condition, and should not therefore be considered by a court. On the one hand, whilst it is clear that the Government placed explicit reliance on the Law Commission report, on the other hand, the Government appeared not to understand that it is not possible to avoid 'major change' - to reaffirm and not to 'repeal in any way' the Rule in Foss $v$ Harbottle - while at the same time abolishing the wrongdoer control requirement and, thereby, the proper plaintiff rule. It had to be one or the other because the wrongdoer control requirement does not reside merely in a detachable exception to the rule; it is an expression of the fundamental

\footnotetext{
140 Standing Committee D, Company Law Reform Bill 13 July 2006. Column No. 665.

141 Standing Committee D, Company Law Reform Bill 13 July 2006. Column Nos 679 and 680.

142 Standing Committee D, Company Law Reform Bill October 2006 Column 832.

${ }^{143} \mathrm{R} v$ Secretary of State for Environment, Transport and the Regions, Ex parte Spath Holmes Ltd [2001] 2 AC 349 at 398 per Lord Nicholls noting further that 'if the parliamentary statements relied on are not clear, they are of little or no value and cannot qualify as an external aid in the particular case'.
} 
rule. That is, in these statements the ministers say that wrongdoer control was not abolished and abolished in the same breath.

Although, most corporate lawyers will feel that intended abolition may well overall be the better reading of the legislative history, to get there one needs to read between the lines, which Pepper $v$ Hart does not allow. Pepper $v$ Hart does not permit courts to attempt determine what ministers 'really meant' or to parse and filter inconsistent statements. If there are inconsistent statements then all statements are inadmissible. As Lord Bingham observed in Spath Holmes the court cannot 'be drawn into comparing one statement with another'. Accordingly, our assessment of the current status of the proper plaintiff rule must be based on Part 11 alone read in the context of the prior common law rules and the context provided by the Explanatory Notes to the Bill.

\section{ALTERNATIVE PATHS TO WRONGDOER CONTROL}

In assessing whether the Act should be interpreted as abolishing or retaining a wrongdoer control threshold condition we need also to evaluate the alternative ways in which the Act may allow courts to take account of a still applicable proper plaintiff rule. Roth J in Bamford $v$ Harvey and Judge Pelling in Stimpson v Southern Private Landlords Association offer such an alternative. For Roth J, in particular, as the proper plaintiff rule remains the guiding principle of the law in this context, the question of whether the company is capable of acting for itself needs to be factored into the permission decision. In both Roth J and Judge Pelling's view as section 263(3) provides for a non-exclusive list of factors, the presence or absence of wrongdoer control may be taken into account at this final stage of the permission proceeding.

We have noted above the logical inconsistency of holding that the proper plaintiff rule is unaltered whilst rejecting the wrongdoer control as a threshold requirement. ${ }^{144}$ Although this conflict can be somewhat assuaged by viewing the proper plaintiff rule as a 'guiding principle' rather than an applicable rule of law and taking account of corporate capability through 263(3), this approach is taken at the expense of the logical structure of 263(3). By introducing wrongdoer control through section 263(3) a hierarchy of considerations is introduced to a provision that on its face provides for a set of unweighted possible considerations which share a common purpose. For Judge Pelling the absence of wrongdoer control may be an 'overwhelming' consideration and for Roth $\mathrm{J}$ although he protests that he is not 'elevating wrongdoer control to a preclusive condition' his holding appears to be very close to such a condition:

144 See text to notes 59-60. 
When proceedings can clearly be brought in the name of the company and there is no objection raised on that ground, they should be brought in the name of the company (emphasis added).

Wrongdoer control is prioritised not only because it is the product of a 'guiding principle' but also because its consideration through 263(3) introduces a factor that is qualitatively different than the expressly articulated considerations set forth in 263(3). The articulated considerations point the court towards possible evidence that the action is, or is not, in the corporate interest - is it being pursued by a person who in good faith wants to further the corporate interest; would a hypothetical director support the bringing of the action; what did the board actually decide and what was the make-up of that board; what might the disinterested shareholders do if asked to ratify or give their views on the decision? Even the requirement to consider whether the member has an alternative personal remedy - which on its face appears unrelated to the corporate interest - is understood through this lens: where the pursuit of the derivative action is really a cost effective way of negotiating a personal remedy that could be enforced separately, permission is likely to be refused. ${ }^{145}$ In such circumstances necessarily the action is not being brought by a member who views the action as being primarily in the corporate interest. There is then no need to specify a hierarchy of these considerations as they all contribute to an assessment of the same question.

In contrast, the question of whether the company is capable of acting does not have anything to say about whether the action would benefit the company or not, it is purely a question about whether the company is in a position to make that decision itself. It is clearly possible that the company is capable of making the decision and yet in the court's view it would be in the company's interest to pursue that litigation. Where considerations directly conflict, to ensure that judges do 'not sit under a palm tree', ${ }^{146}$ a hierarchy of considerations is necessary. But prioritizing company capability creates an anomalous situation in which a consideration which is not referred to in section 263(3) and which is qualitatively different from the articulated considerations, becomes (in relation to a company where there is no wrongdoer control or other form of corporate disability) the most powerful, if not the only, consideration.

If other courts were to follow this approach we appear to end up in more or less the same substantive place as we would if we were to decide, as argued in this article, that the better reading of Part 11 is one that provides for the retention of a wrongdoer control threshold condition. It is submitted that the later solution is both more consistent with the rules of statutory interpretation and a more logical and cleaner solution than the approach adopted in Bamford $v$ Harvey.

\footnotetext{
145 Iesini v Westrip Holdings Ltd [2010] All ER (D) 108.

146 O'Neill v Phillips [1999] 2 BCLC 1 per Lord Hoffmann quoting Warner J in In re J.E. Cade \& Son [1992] BCLC 213.
} 


\section{CONCLUSION}

For commentators who had long lamented the deficiencies of the Rule in Foss $v$ Harbottle, Part 11 was a fresh start. It was a 'new' derivative claim mechanism. Most importantly, it represented the demise of the wrongdoer control and the 'fraud' pre-requisites to the bringing of a derivative action. Recent first instance judgments in Wishart v Castelcroft Securities Ltd, Cinematic Finance v Ryder and Bamford $v$ Harvey encourage a careful consideration of the basis for this consensus position. Its exploration in this article suggests that we may be guilty of wishful thinking.

The consensus position that Part 11 represents change and not continuity is primarily a function of the discipline's view that the legislative history of Part 11 shows us that the reforms were intended to implement the Law Commission's recommendations to abolish wrongdoer control and subject widely-held companies to some, rather than no, exposure to derivative litigation. This after all is what several, widely cited, ministers stated during the legislative process. The problem, however, is that the judge who is required to consider the contemporary status of the proper plaintiff rule and the role of wrongdoer control must do so through the lenses of a person who: (1) does not think that the Act implements the Law Commission's proposals or responds to its view of the mischief of the common law; (2) has no knowledge of the legislative debate and the ministerial statements made in those debates; and (3) gives little weight to the Explanatory Notes to the Act. When this extra-legislative record is filtered through our rules on statutory interpretation what is left is the mischief addressed by the Act as set forth in the Explanatory Notes to the Bill which provide that the new mechanism was not designed to overturn the common law's well established principles.

A judge asked to consider the status of wrongdoer control as a threshold determination to the bringing of a derivative claim is, therefore, left to make this decision though her reading of the statute in light of the context provided by the Explanatory Notes to the Bill. The statute itself could be read either way. On the one hand it can clearly be read as providing the court with a set of rules to determine when the derivative claim must be discontinued and with a set of considerations to take into account when exercising its permission discretion. From this perspective the proper plaintiff rule and wrongdoer control (as a threshold consideration) are irrelevant as they are not referred to: derivative claims can be brought subject only to the court's permission to continue those claims, which will be given or denied in accordance with the considerations and directions provided in section 263 of the Act. From this perspective, the absence of wrongdoer control or other form of corporate incapability does not operate as an absolute bar to the bringing of an action. However, the statute can also be read as providing a procedure for the application of all prior common law rules, including the proper plaintiff rule. Pursuant to this reading at Stage 1 the court, inter alia, determines whether there is a "'prima facie case" for giving permission' which - relying on the common law's 
understanding of this term - involves a threshold determination of whether the company is capable of acting for itself which in most cases will involve an assessment of whether the wrongdoers control the general meeting. At Stage 2, following the initial finding of general meeting incapability, the court must determine following receipt of evidence from all parties whether the litigation should be permitted to proceed by applying the section 263 criteria. Both these readings are viable. Based on the Act alone, there is not, as our rules of statutory interpretation require, a compellingly clear implication that the proper plaintiff rule as a substantive rule of law has been replaced. When this reading of the Act is coupled with the mischief of the Act identifiable from the Explanatory Notes to the Bill the case for continuity is a strong one.

If this is correct, company lawyers have been led astray by Pepper $v$ Hart. Attention to the detailed holding in Pepper $v$ Hart shows clearly that the admissibility of Parliamentary material is subject to demanding constraints. But the actual holding of a case may diverge from the subsequent life and effects of a case. Pepper $v$ Hart stands in many commentators' mind's eye for the admissibility of the supporting Parliamentary statements which they identify. The identified statements and the interpretations they support may, as is the case with Part 11, generate a consensus view of the effects of law reform. A view which we may struggle to detach ourselves from when we ask carefully whether such statements are in fact admissible after all. As Lord Browne-Wilkinson observed 'having once looked at what was said in Parliament it is difficult to put it out of mind'. ${ }^{147}$

147 Pepper v Hart [1993] AC 593 [117] quoted also by Lord Steyn above n. 116 at 66 when discussing the practical difficulties of separating consideration of the ministerial statements after an exhaustive consideration of the meaning of the statute. 